\title{
Cost-Benefit Analysis and the Structure of the Administrative State: The Case of Financial Services Regulation
}

\author{
Richard L. Revesz ${ }^{\dagger}$
}

The viability and desirability of conducting cost-benefit analysis of financial regulation is a subject of intense academic debate. Opponents claim that such analysis is feasible for environmental regulation but not for financial regulation because of the difference in the benefits that require monetization in the respective areas. This Article argues that the recent debate misses an important part of the problem. In large part, cost-benefit analysis of financial regulation cannot currently be performed successfully because of institutional shortcomings, not analytical difficulties. Compared to Executive Branch agencies, independent agencies, like the major financial regulatory agencies, lack the capacity to do cost-benefit analyses of acceptable quality.

Fortunately, there are good Executive Branch models that could be exported to the financial regulatory agencies. In particular, the Financial Stability Oversight Council could implement a robust coordinating role diffusing macroeconomic expertise, learning from the experience of the Interagency Working Group set up to estimate the damage of one ton of carbon dioxide emissions. Moreover, the President could extend to independent agencies his Executive Order vesting in the Office of Information and Regulatory Affairs the responsibility to review significant federal regulations. Though no President has yet taken this step, in part because of fears of a congressional backlash, the time might now be ripe to do so. And, the financial regulatory agencies could learn from the experience of the Environmental Protection Agency in building significant economic expertise to aid the preparation of cost-benefit analyses.

$\dagger \quad$ Lawrence King Professor of Law and Dean Emeritus, New York University School of Law. I am very grateful for the extraordinary research assistance of Max Yoeli and for the generous financial support of the Filomen D'Agostino and Max Greenberg Research Fund at NYU Law School. This article is an extension of a book chapter previously presented at Administrative Law from the Inside Out: A Conference on Themes in the Work of Jerry Mashaw, which took place at Yale Law School. Portions of Parts II and III will be published by Cambridge University Press as the proceedings of that conference. I also presented prior versions of this Article at law school faculty workshops at New York University, the University of California at Davis, and the University of California at Los Angeles. I benefited greatly from these discussions, as well as from the written comments of Lily Batchelder, Ryan Bubb, John Coates, Christopher Elmendorf, Jerry Mashaw, John Michaels, Nicholas Parrillo, Richard Pildes, Adam Samaha, and Catherine Sharkey. 
The Article also considers the role of judicial review. It takes issue with the influential argument that OIRA review can serve as an alternative to judicial review, showing that such an outcome would be inconsistent with settled principles of administrative law. But OIRA review can lead to more deferential judicial review, by serving as a signal that reviewing courts are likely to find reassuring.

Introduction 546

I. The Application of Cost-Benefit Analysis to Financial Regulation .......550

A. Competing Positions .............................................................550

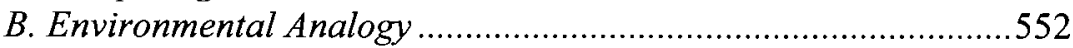

C. Microeconomics v. Macroeconomics ..................................554

D. Macroeconomic Analysis of Environmental Regulation ............556

E. The Road Ahead ................................................................56

II. The Shortcoming of Cost-Benefit Analysis by Independent

Agencies

A. Nuclear Regulatory Commission and the Value of a Statistical Life

B. Securities and Exchange Commission and Its Rulemaking

Problems

C. Commodity Futures Trading Commission and Its Methodological Rescue 570

III. Toward an Institutional Transformation .........................................575

A. Empowering the Financial Stability Oversight Council.............575

B. A Role for OIRA ...................................................................584

C. Building Economic Expertise in Individual Agencies ................592

IV. Role of Judicial Review ..........................................................593

A. OIRA Review v. Judicial Review ...........................................594

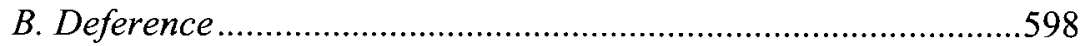

Conclusion .600

Introduction

Recent legal scholarship has focused on the feasibility of performing quantified cost-benefit analysis of financial regulations. An issue of the Yale Law Journal, published in January 2015, compellingly presents the competing positions. John C. Coates IV conducted case studies attempting to apply costbenefit analysis to six representative financial regulations and concluded that "precise, reliable quantifiable" analysis is currently "unfeasible." Eric A.

1. John C. Coates IV, Cost-Benefit Analysis of Financial Regulation: Case Studies and Implications, 124 YALE L.J. 882, 1011 (2015). While Coates opposes quantified cost-benefit analysis, he 
Posner and E. Glen Weyl rebut Coates's arguments that the financial sector poses a unique challenge for cost-benefit analysis and argue that the nature of finance actually makes it highly suitable for quantified analysis. ${ }^{2}$ Similarly, Cass Sunstein argues that "there is no obvious reason ... that financial regulation cannot be subject to [cost-benefit] analysis."3 Finally, Bruce R. Kraus traces the improvements in quantification at the Securities and Exchange Commission (SEC), arguing that the Commission's "response to successful challenges to its rules has produced real progress in the SEC's rulemaking process." 4

In the public policy arena, there have been strong pleas for expanding the use of cost-benefit analysis in the financial regulatory sector. For example, the Center for Capital Markets Competitiveness (which is part of the U.S. Chamber of Commerce) issued a report advocating for the extension of "rigorous costbenefit analysis" to "all financial services regulators." Similarly, the American Enterprise Institute (AEI) called for "a statutory requirement for economic analysis at federal financial regulators, modeled after the analysis required of Executive Branch federal agencies under executive orders."6 Ultimately, AEI lays out a process for "future financial rulemaking" that includes "[i]udicial, congressional, and peer review" as well as "retrospective analysis."7

Cost-benefit analysis is an important tool for the evaluation of the desirability of regulatory actions: "Where all benefits and costs can be quantified and expressed in monetary units, ... [it] provides decision makers with a clear indication of the ... alternative that generates the largest net benefits to society." ${ }^{8}$ In the debate regarding the use of cost-benefit analysis in financial regulation, the questions of whether such analysis should occur, how it should be carried out, and what degree of quantification is practicable monopolize much of the debate. But, in contrast, comparatively little attention is paid to the institutional design in which cost-benefit of financial regulation is

is in favor of "conceptual" cost-benefit analysis, which he sees "as a disciplined framework for specifying baselines and alternatives, for ensuring that ... both costs and benefits of a rule are considered, and for encouraging reliance on "evidence" compared to "quantified or guesstimated" analysis. Id. at $892-93$.

2. Eric A. Posner \& E. Glen Weyl, Cost-Benefit Analysis of Financial Regulations: $A$ Response to Criticisms, 124 YALE L.J.F. 246, 247-57 (2015), http://www.yalelawjournal.org/forum/ cost-benefit-analysis-of-financial-regulations.

3. Cass R. Sunstein, Financial Regulation and Cost-Benefit Analysis, 124 YALE L.J.F. 263, 270 (2015), http://www.yalelawjoumal.org/forum/financial-regulation-and-cost-benefit-analysis.

4. Bruce R. Kraus, Economists in the Room at the SEC, 124 YALE L.J.F. 280, 280 (2015), http://www.yalelawjournal.org/forum/economists-in-the-room-at-the-sec.

5. PAUl ROSE \& Christopher J. WAlKer, CTR. FOR CAPITAL MKTS. COMPETITIVEness, THE IMPORTANCE of COST-Benefit ANALysis In FinANCIAL Regulation, at $v$ (2013).

6. AbBy McCloskey \& Hester Peirce, Am. Enter. Inst., Holding Financial. REGULATORS ACCOUNTABLE: A CASE FOR ECONOMIC ANALYSIS 1 (2014).

7. Id. at 10-11.

8. U.S. OfFICE OF MGMT. \& Budget, CirCular A-4 at 1-2 (Sept. 17, 2003), https:/georgewbush-whitehouse.archives.gov/omb/circulars/a004/a-4.pdf [hereinafter CIRCULAR A-4]. 
carried out. ${ }^{9}$ Thus, this Article focuses on institutional matters, arguing that the current structural arrangements for conducting cost-benefit analyses of financial regulation are clearly suboptimal. ${ }^{10}$ The independent agencies that have primary responsibility for financial regulation lack the capability to conduct cost-benefit analyses of the quality that is commonplace in the Executive Branch, in part as a result of the role of the Office of Information and Regulatory Affairs (OIRA). ${ }^{11}$

These institutional shortcomings are now particularly ominous in light of the Supreme Court's recent decision in Michigan v. EPA, ${ }^{12}$ which Sunstein heralded "as a ringing endorsement of cost-benefit analysis by government agencies." "In this case, the Court invalidated a rule by the Environmental Protection Agency (EPA) limiting the emission by power plants of certain hazardous air pollutants, on the grounds that the agency had not considered costs in making the statutory determination that the rule was "appropriate and necessary." 14 Ironically, the Michigan v. EPA decision is unlikely to have much impact on environmental regulations because open-ended terms like "appropriate and necessary" are rare in federal environmental laws. In contrast, these terms are commonplace in statutes that delegate rulemaking authority to financial regulators, rendering their rules potentially vulnerable, absent consideration of costs and benefits. For example, the SEC's governing statute requires agency rulemakings to "consider or determine whether an action is necessary or appropriate in the public interest." ${ }^{\text {. }}$ Similarly, the Dodd-Frank Wall Street Reform and Consumer Protection Act uses "necessary or appropriate" or "necessary and appropriate" language eighty times in a variety of contexts. ${ }^{16}$ As a result, the requirement that the financial regulatory agencies engage in cost-benefit analysis is now likely to become more prevalent.

Focusing on the institutional reforms necessary to improve the quality of the cost-benefit analyses performed by financial regulatory agencies is therefore an important challenge. The administrative state must embrace this challenge to ensure that cost-benefit analyses are of sufficient quality to withstand judicial scrutiny.

9. See, e.g., Ryan Bubb, Comment: The OIRA Model for Institutionalizing CBA of Financial Regulation, 78 LAW \& CONTEMP. PROBS. 47, 47 (2015).

10. See Robert P. Bartlett III, The Institutional Framework for Cost-Benefit Analysis in Financial Regulation: A Tale of Four Paradigms?, 43 J. LEGAL STUD. S379, S403 (2014).

11. See Bubb, supra note 9 , at 5053.

12. 135 S. Ct. 2699 (2015).

13. Cass R. Sunstein, Thanks, Justice Scalia, for the Cost-Benefit State, BLOOMBERG VIEW (Jul. 7, 2015), http://www.bloombergview.com/articles/2015-07-07/thanks-justice-scalia-for-thecost-benefit-state.

14. 135 S. Ct. at $2711-12$.

15. 15 U.S.C. $\$ 77 b(b)(2012)$.

16. Dodd-Frank Wall Street Reform and Consumer Protection Act, Pub. L. No. 111203, $\S \S 726,1076$ (2010) (codified at 12 U.S.C. $\S 5301$ ) [hereinafter Dodd-Frank]. 
Part I surveys the debate on the cost-benefit analysis of financial regulation. Even the opponents of the use of cost-benefit analysis for financial regulation argue that the technique has worked well for environmental regulation. But financial regulation, they maintain, presents different issues altogether. The main distinction, which is not always made explicit, is that most cost-benefit analyses of environmental regulation rely on microeconomic models: if emissions from a source are constrained, what will the impact be on that source's level of activity and on the price of its product? In contrast, the cost-benefit analysis of financial regulation necessarily requires macroeconomic assessments: how do restrictions on the activity of banks affect the probability of an economy-wide crisis? It turns out, however, that environmental cost-benefit analysis has also recently begun to rely on macroeconomic models, examining, for example, the impact of regulation on economy-wide prices and employment. In contrast, the financial regulatory agencies have not made similar investments in the development of such techniques.

Part II uses three case studies to illustrate the shortcomings of independent agencies with respect to cost-benefit analysis. The first involves efforts by the Nuclear Regulatory Commission (NRC) to update its estimate of the Value of a Statistical Life (VSL). The other two deal with key financial regulators: the adoption by the SEC of OIRA's approach to cost-benefit analysis, though only after having some significant regulations struck down by the D.C. Circuit; and the request by the Commodity Futures Trading Commission (CFTC) that OIRA provide it with technical assistance.

Part III focuses on institutional changes designed to improve the quality of the cost-benefit analyses prepared by the financial regulatory agencies. Possible improvements include expanding the role for the Financial Stability Oversight Council (FSOC), ${ }^{17}$ granting OIRA a formal role in the review of the costbenefit analyses supporting regulatory action, ${ }^{18}$ and enhancing the economics capabilities of individual agencies. In each of these cases, the Executive Branch provides good models for independent agencies to emulate. This Part also adds an important functional argument to the structural argument for why the forcause removal provisions that protect the heads of independent agencies should not be invoked to expand the scope of the independence of these agencies beyond what Congress provided.

Part IV examines the role of judicial review in administrative rulemaking and compares it to OIRA review. Some financial regulation commentators have decried the former but embraced the latter. They maintain that OIRA review should be an alternative to judicial review. But this approach misunderstands a fundamental component of the administrative state: any cost-benefit analysis

17. See Jacob E. Gersen, Administrative Law Goes to Wall Street: The New Administrative Process, 65 ADMIN. L. REV. 689, 692-93 (2013).

18. See Bubb, supra note 9, at 50-53. 
prepared by an agency for the purpose of OIRA review would be subject to judicial review as well. Nonetheless, OIRA review can produce higher quality cost-benefit analyses and lead to more deferential judicial review.

\section{The Application of Cost-Benefit Analysis to Financial Regulation}

The focus here is on the debate surrounding the application of cost-benefit analysis to financial regulation. After tracing the contours of the academic debate, this Part analyzes how opponents of cost-benefit analysis of financial regulation have distinguished it from the cost-benefit analysis of environmental regulation. The core argument advanced in this Part is that the need for financial regulation to be evaluated through macroeconomic models does not make cost-benefit analysis inappropriate. Instead, our regulatory institutions should invest resources in developing quantification techniques, as is currently being done in the environmental arena.

\section{A. Competing Positions}

Cost-benefit analysis has long been ingrained in federal regulatory policymaking, particularly in connection with reducing environmental, health, and safety risks. In contrast, the merits of monetizing benefits of financial regulation are the subject of robust debate. At the center of this conflict is the issue of how challenging it would be to quantify regulatory benefits in the financial space. The outcome of the debate surrounding the application of costbenefit analysis to financial regulation may have significant implications for the American (and thus global) economy as well as for the landscape of the regulatory state and accompanying body of administrative law.

Coates, perhaps the most sustained critic of efforts to use cost-benefit analysis in financial regulation, argues that cost-benefit analysis in financial regulation fails its own measure and that, as "precise, reliable quantifiable [analysis] remains unfeasible ... judicial review of quantified [cost-benefit analysis] of financial regulation is not likely to generate benefits that exceed its costs" in the short term. ${ }^{19}$ In particular, Coates offers three core reasons why the analysis of financial regulation is inherently difficult: the centrality of finance to the broader economy, the "social and political" human elements of financial behavior, and the financial sector's susceptibility to shocks and innovations that produce quick changes. ${ }^{20}$ As a result, he concludes that the ability to "conduct quantified [cost-benefit analysis in financial regulation] with any real precision or confidence does not exist for important, representative types of financial regulation., 21

19. Coates, supra note 1 , at 1011 .

20. Id. at $998-1003$.

21. Id. at 997-98. In a separate contemporaneous piece, Coates discusses approaches to increase the viability of cost-benefit analysis in financial regulation. John C. Coates IV, Towards 
In contrast, Sunstein's rebuttal defends financial regulation as a suitable arena for quantified cost-benefit analysis and sets forth breakeven analysis as an alternative for when traditional cost-benefit analysis is not feasible. ${ }^{22}$ In this connection, Sunstein describes breakeven analysis as "a way of engaging in cost-benefit analysis when important information is missing." 23 So, for example, an agency that quantifies a rule's benefits might at least be able to "specify how high the benefits would have to be to justify the costs" and that this inquiry would "discipline the judgment about whether to proceed.",24

In turn, Posner and Weyl contend that Coates "conflates two separate issues: the advisability of [cost-benefit analysis] and the uncertainty of [costbenefit analysis] valuations," and proceed to rebut, point-by-point, his opposition to its use in financial regulation. ${ }^{25}$ They conclude that cost-benefit analysis fits financial regulation at least as well if not better than other regulatory areas. ${ }^{26}$ Posner and Weyl support "greater investment in academic research" rather than the "abandonment of [cost-benefit analysis]."27 They argue that Coates is excessively skeptical of quantification, emphasizing that the issue of "uncertain valuations is a commonplace of regulation," regardless of the sector. ${ }^{28}$

Finally, Kraus, a former SEC official, ${ }^{29}$ argues that the SEC is currently undergoing the improvements Coates and others seek. ${ }^{30}$ Kraus contends that SEC's "response to successful challenges to its rules has produced real progress in the SEC's rulemaking process." 31 Although Kraus admits that there are flaws in cost-benefit analysis as applied to financial regulation, he applauds the improvements in quantification that have occurred within the Division of Economic and Risk Analysis at the SEC. ${ }^{32} \mathrm{He}$ attributes these improvements in part to institutional changes such as the enhanced integration of economists into policymaking processes. ${ }^{33}$

Better Cost-Benefit Analysis: An Essay on Regulatory Management, 78 LAW \& CONTEMP. PROBS. 1 (2015).

22. Sunstein, supra note 3 , at 274 .

23. Id. at 271 .

24. Id. at 271-72.

25. Posner \& Weyl, supra note 2, at 246.

26. Id. at 262 .

27. Id. at 246 .

28. Id. at $247-50$

29. Bruce Kraus, LINKEDIN (last visited July 31, 2015), http://www.linkedin.com/ pub/bruce-kraus/10/38b/281.

30. Kraus, supra note 4, at 280.

31. Id.

32. Id. at 283 .

33. Id. at $281,302-03$. 


\section{B. Environmental Analogy}

The pioneering of cost-benefit analysis and of techniques for quantifying regulatory impacts took place largely in the environmental sphere. Compared to the environmental context, the absence of extensive quantified cost-benefit analysis in the financial space presents a "stark contrast." 34 Several scholars invoke characteristics of environmental regulatory analysis to argue by analogy for or against the feasibility of cost-benefit analysis in financial regulation.

Skeptics of the cost-benefit analysis of financial regulation draw distinctions between the environmental and financial contexts in an effort to explain why efforts in the latter would fall short of the successes they attribute to the former. Coates, for example, rejects the notion that analysis in the environmental realm is replicable in finance, positing that chemical interactions in the environment "are generally simpler than interactions of groups of humans," which finance entails. ${ }^{35}$

This sentiment echoes Jeffrey Gordon, who maintains that there is a "difference between 'natural' and 'constructed' systems." 36 According to Gordon, a natural system is one in which costs and benefits "do not change (or change much) no matter what the central planner does," as in the environmental context. $^{37}$ For example, certain events drive certain outcomes, regulation notwithstanding: "the health effects of a particular atmospheric emission . . . do not change if the planner reduces the risk-exposure levels." ${ }^{38}$ Gordon and other proponents of this argument, however, misunderstand the nature of environmental regulation, which is to regulate human activity. While the effects of reduced pollution on the environment respond to the laws of physics and chemistry, the responses to regulation are dependent on the decisions of human beings.

In contrast to environmental regulation, Gordon argues that the financial system is "a system constructed by the pattern of financial regulation itself and by the subsequent processes of adaptation and regulatory arbitrage," claiming that we lack "the foresight to forecast how that system will evolve." 39 Rather than balancing costs and benefits as in the environmental context, Gordon believes that cost-benefit analysis in financial regulation "is based on a series of trade-offs of normatively derived values." 40 Weighing normative priorities, he worries, will engender "principles of pragmatic design" that operate based on

34. Bubb, supra note 9, at 49 .

35. Coates, supra note 1, at 1001.

36. Jeffrey N. Gordon, The Empty Call for Benefit-Cost Analysis in Financial Regulation, 43 J. LEGAL STUD. S351, S352 (2014).

37. Id. at $\mathrm{S} 351$.

38. Id. at $\mathrm{S} 352$.

39. $I d$.

40. Id. at $\mathrm{S} 351$. 
controversial inputs. ${ }^{41}$ As such, he believes that cost-benefit analysis offers no advantage in assessing regulatory impacts in financial regulation, and worries that it will serve only to perpetuate a suboptimal "status quo," particularly when coupled with judicial review. ${ }^{42}$

Similarly, John Cochrane argues that environmental regulation is "much more straightforward" "[e]conomic elasticities," which are "harder to calculate than equipment costs and medical benefits." an environment in which all sides of the debate could pretty much agree what costs and benefits mean," but fears the same does not hold true for financial regulation. $^{45}$

Posner and Weyl reject the distinctions Coates and others draw between regulating the environment and financial sector. They claim that "economists understand financial markets at least as well as scientists understand the environment or the human body" and that financial valuations are nearly exclusively monetary and thus more readily quantifiable than "valuations that are relevant to environmental, health, and safety regulation." 46 According to Posner and Weyl, because of the bulk of data financial activity creates, "financial regulations are ideal for [cost-benefit analysis] — much more suitable than regulations of the environment and health and safety."47 Further, they argue that, while environmental regulation has had to grapple with "valuing intangible assets, ... almost all financial benefits and costs can be measured in terms of utility functions over money, the area of economics with the longest history ... and the area most firmly understood by economists. ${ }^{, 48}$ In addressing the objection that financial activity relies on human behavior rather than physical systems, Posner and Weyl reply that "[c]ompared to other areas of economics like industrial organization, which is the foundation of antitrust [cost-benefit analyses], financial economics has a far stronger track record of accurate prediction and precise mathematical modeling." 49 They also underscore that, unlike the claims of the critics, environmental regulators also deal with people and groups. ${ }^{50}$

Finally, in drawing a connection between progress in the environmental arena and opportunity in financial regulation, Sunstein invokes the state of environmental regulatory analysis in the 1970 s. To him, that era was a time

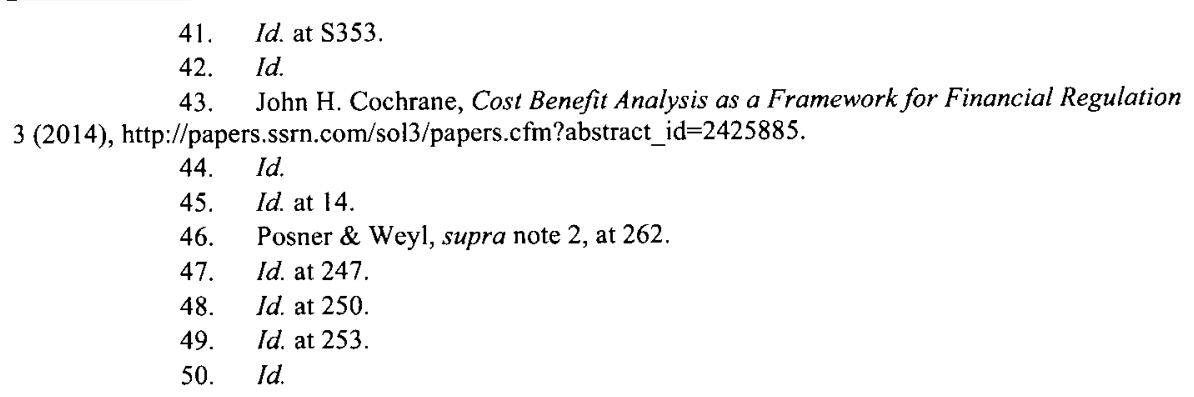


"when cost-benefit analysis seemed, to many observers and participants, to be impossibly daunting." $\mathrm{He}$ suggests that, though regulating the financial industry may seem like a Herculean task today, " $[t]$ here is no obvious reason, in principle, that financial regulation cannot be subject to [cost-benefit] analysis, either now or in the future." 52

\section{Microeconomics v. Macroeconomics}

Though this distinction is not clearly articulated in the literature, at the core of the debate on whether cost-benefit analysis of financial regulation differs from cost-benefit analysis of environmental regulation is the distinction between microeconomic and macroeconomic models. ${ }^{53}$ Detractors of the use of cost-benefit analysis in financial regulation argue that the need to predict macroeconomic conditions as opposed to microeconomic behavior poses a fatal impediment to cost-benefit analysis. ${ }^{54}$ Others, however, disagree about the significance of this distinction. ${ }^{55}$ Much of the rhetoric about the inherent differences between the two types of regulatory systems boils down to the need to model macroeconomic impacts in the case of financial regulation.

In this connection, Coates focuses on three primary impediments. ${ }^{56}$ First, he argues that performing cost-benefit analysis on financial regulation is different because "finance is at the heart of the economy." 57 As a result, rules influence the economy in unpredictable and outsize ways. ${ }^{58}$ Drawing a contrast to a more straightforward safety regulation, Coates underscores his assertion that "[m]acroeconomic models that include finance are still highly contested" and thus cannot anchor high-quality cost-benefit analysis. ${ }^{59}$ Second, he argues that predicting how individuals, groups, firms, markets, and governments will react to regulation is fundamentally different from instances in which "objects of regulation are inanimate" and physical principles hold constant. ${ }^{60}$ Finally, Coates explains that because the financial sector is "non-stationary," the

51. Sunstein, supra note 3 , at 275 .

52. Id.

53. One commentator has recently embraced paying further attention to the connection between law and macroeconomics, suggesting that law should "do more to promote spending in deep recessions than in ordinary economic conditions." Yair Listokin, Law and Macroeconomics: The Law and Economics of Recessions 4 (Yale Law \& Econ. Research Paper No. 559, 2016), https://papers.ssm.com/sol3/papers2.cfm?abstract id=2828352.

54. See, e.g., Coates, supra note 1, at 1000; Cochrane, supra note 43, at 5 .

55. See, e.g., Yair Listokin, Law and Macroeconomics 17 (Oct. 2, 2014) (unpublished manuscript), http://law.stanford.edu/wp-content/uploads/sites/default/files/event/719308/media/slspublic /Yair\%20Listokin\%20-\%20Law\%20and\%20Macroeconomics.pdf (discussing financial regulation as one area where law and macroeconomics is present and advocating for further use of macroeconomic analysis in the law); Posner \& Weyl, supra note 2, at 250-51.

56. Coates, supra note 1 , at $998-1003$.

57. Id. at 999 .

58. Id. at 999-1001

59. Id. at 1000 .

60. Id. at 1001 . 
benefits of regulation are excessively difficult to quantify. ${ }^{61} \mathrm{He}$ claims that innovation has had a rapid and formidable impact in the financial services industry, thus making the analysis of regulatory impacts more difficult than in industries in which scientific disciplines like "physics, chemistry, and biology" play a larger role. $^{62}$

Similarly, Gordon argues that the financial sector is unfit for cost-benefit analysis due to its existence as a "constructed" system, with regulations having a ripple effect on the system itself. ${ }^{63}$ Gordon's outlook on cost-benefit analysis is that it is "virtually useless" for analyzing regulation in the financial sphere because "markets are jointly produced by rules and the response to rules." According to Gordon, the macroeconomic impacts of financial rulemaking make it impervious to quantified regulatory analysis.

Along the same lines, Cochrane contends that financial costs and benefits "resist the kind of objective quantification that is necessary" for useful costbenefit analysis and worries that such a process would be "captured and derailed." 65 Cochrane shares Coates's skepticism regarding assessing macroeconomic factors and suggests that "micro-financial regulation seem [sic] more amenable to cost-benefit analysis" because "it stays away from nebulous general-equilibrium effects and behavioral responses" like projecting reactions to regulation. ${ }^{66}$

Posner and Weyl disagree with the argument that the "nature of financial markets" makes them unsuitable for regulations justified by cost-benefit analysis. $^{67}$ They posit that cost-benefit analysis is particularly suitable for financial regulation because the centrality of financial services warrants the investment of undertaking such an involved study. They also dismiss Coates's worry that causal complexities of prediction and ripple effects in the financial system would make forecasting difficult, arguing that this problem is "generic" to cost-benefit analysis. ${ }^{68}$ And, they take issue with Coates's point that human behavior affects finance uniquely. ${ }^{69}$

More generally, prominent economic policy commentators, such as former Member of the Council of Economic Advisors and Acting Director of the Congressional Budget Office (CBO) Donald B. Marron and former Director of the CBO Douglas Elmendorf, have embraced macroeconomic forecasting in the form of dynamic scoring of legislative proposals. ${ }^{70}$ Dynamic scoring

61. Id. at 1002-03.

62. Id.

63. Gordon, supra note 36 , at 1.

64. Id. at 2-3.

65. Cochrane, supra note 43 , at 2 .

66. Id. at 11 .

67. Posner \& Weyl, supra note 2, at 246-47.

68. Id. at $250-52$.

69. Id. at 252-53.

70. See Donald B. Marron, Thoughts on Dynamic SCORING OF Fiscal Policies, TAX POLICY CENTER (June 2016), http://www.taxpolicycenter.org/sites/default/files/alfresco/publication 
includes macroeconomic effects to assess a policy in terms of economy-wide impacts, rather than assuming the absence of far-reaching consequences. ${ }^{71}$ Dynamic scoring performs the same function as cost-benefit analysis of financial regulations with macroeconomic impacts - both seek to ascertain the outcomes of proposed policies with reference to the entire economy. Thus, the use of dynamic scoring in legislative contexts provides support for the use of macroeconomic forecasting in policy contexts.

Despite different political viewpoints and having worked for administrations of different parties, the two experts agree that the CBO and Joint Committee on Taxation (JCT) "should account for macroeconomic feedback when scoring proposed legislation" through dynamic scoring. ${ }^{72}$ Marron specifically applauds the CBO and JCT's efforts in "developing and refining their macroeconomic modeling techniques for more than a decade."73 Ultimately, both recommend the immediate adoption of dynamic scoring that includes macroeconomic feedback in analyzing major legislation, noting that the offices had previously taken macroeconomic effects into account in analyzing various immigration reform proposals as well as budget baselines, produced twice a year. ${ }^{74}$ Finally, both experts dismiss concerns with macroeconomic forecasting, such as "uncertainty and the risk of bias," by pointing to the nonpartisanship of $\mathrm{CBO}$ and JCT and describing how macroeconomic forecasting will make analysis more reliable. ${ }^{75}$

\section{Macroeconomic Analysis of Environmental Regulation}

The use of macroeconomic models is not foreign to cost-benefit analysis, though it is still in its infancy. As with respect to other aspects of cost-benefit methodologies, the EPA has taken the lead. Its Guidelines for Preparing Economic Analyses provide that, when meaningful changes in one sector may lead to indirect consequences in other sectors, "a general equilibrium framework, which captures linkages between markets across the entire economy, may be a more appropriate choice." 76

In particular, the agency has turned to computable general equilibrium (CGE) modeling to forecast how the economy will respond to potential changes in environmental policy. These models "simulate the workings of the price

\footnotetext{
-pdfs/2000829-Thoughts-on-Dynamic-Scoring-of-Fiscal-Policies.pdf; Douglas W. Elmendorf, "Dynamic Scoring": Why and How to Include Macroeconomic Effects in Budget Estimates for Legislative Proposals, BROOKINGS PAPERS ON ECONOMIC ACTIVITY (Fall 2015), http://www.brookings.edu/wp-content/uploads/2015/09/ElmendorfTextFall15BPEA.pdf.

71. See Elmendorf, supra note 70 , at 92.

72. MARRON, supra note 70, at 1 ; see Elmendorf, supra note 70, at 91-92.

73. MARRON, supra note 70 , at 1 .

74. Id. at 1-3; Elmendorf, supra note 70 , at $91-93,96$.

75. MARRON, supra note 70, at 3-4; Elmendorf, supra note 70 , at $117-20$.

76. U.S. EnvtL. Protection AgenCy, Guidelines for Preparing Economic Analyses, EPA 240-R-10-001, at 8-4 (2010), http://yosemite.epa.gov/ee/epa/eerm.nsf/vwAN/EE-056850.pdf/\$file/EE-0568-50.pdf [hereinafter EPA Guidelines].
} 
system in a market economy."77 The CGE approach is macroeconomic in that the models can be used to estimate "impacts of policies that are expected to have relatively large, economy-wide effects," accounting for the interaction between environmental regulation and "pre-existing distortions in the economy.",78

EPA describes a number of advantages and disadvantages of CGE modeling. On the plus side, CGE models are well equipped to forecast "large economy-wide impacts, especially when indirect and interaction effects are expected to be significant."79 Other advantages include the ability of CGE models to forecast regulatory impacts over a long time horizon and their capacity to "estimate the distributional impacts of policy shocks on household groups or industrial sectors." 80 However, the EPA also notes the tool's limitations: CGE models are ill-suited to "analyzing short-run transitional costs" absent appropriate specifications and are a poor fit for analyzing policies with narrow impacts in terms of limited sectors or geography, especially in light of the costs such modeling entails. ${ }^{81}$

CGE models estimate the impact of a change in policy by "'shocking' the model" with the proposed regulation. After this shock, the market reaches a new equilibrium. ${ }^{82}$ From the change in equilibria, economists can distill "changes in economic welfare measures," either at one point in time or over time. ${ }^{83}$ CGE models can therefore estimate the macroeconomic impacts of major regulatory changes.

The EPA has used CGE models in a variety of regulatory proceedings and analyses, including in a significant retrospective cost-benefit analysis of the Clean Air Act. ${ }^{84}$ The agency has also used these models prospectively to quantify the costs of mitigating greenhouse gases in a variety of contexts, including the Kyoto Protocol and proposed congressional action on climate change. $^{85}$

To analyze air quality regulations, the EPA has used a CGE model in conjunction with an Intertemporal General Equilibrium Model, ${ }^{86}$ following a

77. Id. at $8-19$.
78. Id. at $8-21$.
79. Id.
80. Id.
81. Id.
82. Id. at $8-19$.
83. Id.
84. Id. at $8-20 ;$ OFFICE OF AIR \& RADIATION \& OFFICE OF POLICY, PLANNING AND Evaluation, U.S. Envtl. Protection Agency, The Benefits and Costs of THE Clean Air act: 1970-1990, EPA/4 10/R-97/002 (1997).

85. EPA Guidelines, supra note 76 , at 8-20.

86. Economy-Wide Modeling: Social Cost and Welfare White Paper 45 (Sept. 22, 2015), http://yosemite.epa.gov/sab/sabproduct.nsf//LookupWebProjectsCurrentBOARD/07E67CF77B 54734285257BB0004F87ED/\$File/Social+Cost+and+Welfare+White+Paper+9-22-15.pdf. 
peer review of both models. ${ }^{87}$ In some cases, the agency has relied solely on CGE modeling, as was the case for its Regulatory Impact Analysis for the Ozone National Ambient Air Quality Standards (NAAQS). ${ }^{88}$ In this proceeding the EPA assessed, on an economy-wide basis, the potential impacts of an alternate ozone standard. ${ }^{89}$ The model was likewise used to estimate social costs. $^{90}$ The EPA employed a similar analysis to analyze the Clean Air Interstate Rule and Clean Air Visibility Rule, ${ }^{91}$ two critically important Clean Air Act regulations.

More recently, the EPA began exploring the potential expansion of its macroeconomic modeling, as a result of pressure from the Senate in connection with the confirmation of Gina McCarthy to be the EPA Administrator. David Vitter of Louisiana and other Republican members of the Senate Committee on Environment and Public Works stalled McCarthy's nomination. ${ }^{92}$ In this connection, the Senators made five demands targeted at making the EPA more "transparent." 93

One core demand was that the EPA disseminate "new guidance mandating 'whole economy' modeling on major rules." 94 Specifically, the Republicans on the Committee objected to the EPA's use, in most instances, of "only a partial economy analysis of the impact of the rules versus an economy-wide analysis when proposing and finalizing individual rules." 95 The Senators pointed out that the EPA had used CGE models for only two rules. For all others, they claimed, the agency had not studied the effects "in other sectors not directly subject to the regulation's compliance requirements." Instead, the EPA had used a "basic job multiplier formula," which estimates a fixed jobs impact per

87. U.S. ENVtl. Protection Agency, Response to Peer ReViews of EPA'S EMPAX COMPUTER GENERAL EQUILIBRIUM MODEL (2006), http://yosemite.epa.gov/sab/ SABPRODUCT.NSF/81 e39f4c09954fcb85256ead006be86e/07E67CF77B54734285257BB0004F87ED /\$File/Social+Cost+and+Welfare+White+Paper+9-22-15.pdf; U.S. ENVIRONMENTAL PROTECTION AGENCY, Peer Review of Computable General Equilibrium Models for Climate Change Analysis (2010), http://www3.epa.gov/climatechange/Downloads/EPAactivities/

Final_peer review report for IGEM and ADAGE.pdf.

88. U.S. ENVTL. PROTECTION AGENCY, FINAL OZONE NAAQS REgULATORY IMPACT ANALYSIS, EPA 452/R-08-003, at 5-2 to 5b-25 (2008), http:/www3.epa.gov/ttn/ecas/regdata/ RIAs/452_R_08_003.pdf.

89. Id. at $5 \mathrm{~b}-1$.

90. Id. at $5 \mathrm{~b}-2$

91. Id.

92. Erica Martinson, What Vitter Got for Blocking McCarthy, POLITICO (July 11, 2013), http:/www.politico.com/story/2013/07/david-vitter-epa-gina-mccarthy-093993.

93. Id; see Eye on the EPA: Transparency Request \#4, Snapshot Approach Toward Economic Analysis Doesn't Work, U.S. SENATE COMMITTEE ON ENVIRONMENT \& PUBLiC WORKS (Apr. 25, 2013), http://www.epw.senate.gov/public/index.cfm/in-the-news?ID=4310AC51-EF70-4C02-03EACBF64C1486C2.

94. Eye on the EPA: Transparency Request \#4, Snapshot Approach Toward Economic Analysis Doesn't Work, supra note 93 (articulating concerns on behalf of "the EPW Republican Senators").

95. Id.
$96 . \quad I d$.


amount of "compliance spending" resulting from a rule." The Senators objected that the EPA's job multiplier technique "fails to capture the scenario of a regulation's cost being passed to the ultimate end user: the customer." 98

In response to the Committee's demands, the EPA agreed to create an expert group to assist with its CGE modeling. ${ }^{99}$ As a result, the EPA's Science Advisory Board established a panel on Economy-Wide Modeling, of which I am a member. The panel was charged with examining "the technical merits and challenges, and potential value added of economy-wide modeling to evaluate social costs, benefits, and/or economic impacts of air regulations as a supplement to partial equilibrium or engineering approaches." It was also asked to "identify potential paths forward for improvements in economy-wide models that could address existing limitations and increase their potential utility as analytic tools to support regulatory decisions."100 Three white papers prepared for the panel include an examination of economy-wide modeling as it pertains to social cost, ${ }^{101}$ air quality benefits, ${ }^{102}$ and alternatives to CGE modeling for quantifying air regulation. ${ }^{103}$ While it is still too early to tell whether CGE modeling will eventually play an influential role in the cost-benefit analysis of environmental regulation, these documents make clear that the EPA is actively exploring the use of macroeconomic, whole-economy modeling when appropriate.

The inability to make macroeconomic predictions is a key argument advanced by opponents of using cost-benefit analysis in financial regulation. ${ }^{104}$ However, the EPA has shown that CGE modeling can be used, at least in some instances, to forecast whole-economy impacts over an extensive time frame. Financial regulators can, and should, learn from the EPA's experience in making macroeconomic forecasts.

97. Id.

98. Id.

99. Martinson, supra note 92.

100. Al MCGartland, U.S. Environmental Protection Agency, Draft Final ChaRge ON THE ROLE OF ECONOMY-WIDE MODELING IN U.S. EPA ANALYSIS OF AIR REGULATIONS 23 (Feb. 26, 2015), http://yosemite.epa.gov/sab/sabproduct.nsf//LookupWebProjectsCurrentBOARD/ 07E67CF77B54734285257BB0004F87ED/\$File/Charge+Questions+2-26-15.pdf.

101. Economy-Wide Modeling: Social Cost and Welfare White Paper, supra note 86.

102. Economy-Wide Modeling: Benefits of Air Quality Improvements White Paper (Sept. 22, 2015), http://yosemite.epa.gov/sab/sabproduct.nsf//LookupWebProjectsCurrentBOARD/ 07E67CF77B54734285257BB0004F87ED/\$File/Benefits tof+Air+Quality+Improvements.pdf.

103. Memo on Using Other (Non-CGE) Economy-Wide Models to Estimate Social Cost of Air Regulation (Sept. 22, 2015), http://yosemite.epa.gov/sab/sabproduct.nsf// LookupWebProjectsCurrentBOARD/07E67CF77B54734285257BB0004F87ED/\$File/NonCGE+Models+to+Estimate+Social+Cost+9-22-15.pdf.

104. Coates, supra note 1 , at 1000. 


\section{E. The Road Ahead}

Elsewhere, I analyzed the difficulties of quantifying the benefits of regulation, ${ }^{105}$ arguing that, over decades of administrative practice, regulatory agencies had "come to quantify important categories of benefits that they once considered nonquantifiable." 106 Examining a set of breakthroughs in valuation techniques over time, I showed that quantified regulatory impacts and those that are, at one point in time, considered nonquantifiable do not belong to "immutable" categories. ${ }^{107}$ In the environmental area, these advances led to the quantification (or movement toward the quantification) of important categories of regulatory benefits, such as the value of a statistical life; the social cost of carbon; ecosystem services; fear, anxiety, and stress; and natural resource options. ${ }^{108}$ Further, I showed that the quantification of a new category of regulatory impact often occurs due to either governmental funding of private research or direct intervention in developing quantification techniques. ${ }^{109}$

Similarly, the benefits of financial regulation should be viewed as currently unquantified, not permanently unquantifiable. And, as explained in more detail in Part III, the financial regulatory agencies should be investing in their economics capabilities, embracing the path that agencies tasked with environmental, health, and safety regulation have traveled for decades.

\section{The Shortcoming of Cost-Benefit Analysis by Independent Agencies}

The capacity of federal regulatory agencies to perform cost-benefit analysis varies widely. The more proficient agencies are in the Executive Branch, and their regulations are subject to OIRA review under Executive Orders $12,866^{110}$ and $13,563 .^{111}$ The less successful agencies are independent and outside the purview of OIRA review. ${ }^{112}$ For example, of 101 major rules promulgated by independent agencies from 2008 to 2013 , only one included a

105. See Richard L. Revesz, Quantifying Regulatory Benefits, 102 CAL. L. REV. 1423 (2014). For an example of one account that is skeptical of quantification, see generally Jeff Schwartz \& Alexandrea Nelson, Cost-Benefit Analysis and the Conflict Minerals Rule, 68 AdMIN. L. REv. 287, 346 (2016) (claiming "[quantified cost-benefit analysis] is not nearly the analytical tool that courts and policymakers seem to think it is" and "challeng[ing] its required use in regulatory analysis").

106. Revesz, supra note 105 , at 1436.

107. Id. at $1425,1436-50$.

108. Id.

109. Id. at $1450-56$.

110. Exec. Order No. $12,866 \S 6,3$ C.F.R. $\$ 638$ (1993);

111. Exec. Order No. 13,563 § 7(a), 3 C.F.R. $\$ 3821$ (2011).

112. Recent empirical evidence supports the proposition that independent agencies do worse cost-benefit analysis than agencies subject to OIRA review. See Howell E. Jackson \& Paul Rothstein, The Analysis of Benefits in Consumer Protection Regulations (unpublished manuscript), https://www.law.ox.ac.uk/sites/files/oxlaw/jackson_and_rothstein_article-_december_2015.pdf.

Specifically, Jackson and Rothstein claim, based on their extensive analysis of seventy-two regulations promulgated by fifteen agencies (seventeen agencies if joint rulemaking partner agencies are taken into account), that "the benefits analyses by the OIRA agencies showed greater quantification effort than did those by the independent agencies." Id. at 32 tbl.1, 109. 
"complete cost-benefit analysis." 113 By comparison, executive agencies issued fifty-four major rules in Fiscal Year 2013 alone. Of these, thirty were "budgetary transfer rules," which "represent payments from one group to another ... that redistribute wealth and do not directly entail social costs or benefits. ${ }^{114}$ of the remaining twenty-four, seven fully quantified costs and benefits, two included solely benefits, and eleven calculated only costs, leaving four entirely without quantification. ${ }^{115}$ In some years, as OIRA pointed out for Fiscal Year 2011, the fully quantified rules constituted "the strong majority of the benefits and costs of the rules issued." $" 116$

The financial regulatory agencies that are independent include the Office of the Comptroller of the Currency (OCC), the Consumer Financial Protection Bureau (CFPB), the Federal Deposit Insurance Corporation (FDIC), the Federal Housing Finance Agency (FHFA), the National Credit Union Administration (NCUA), the Federal Reserve, as well as the SEC and the CFTC. ${ }^{117}$ What follows are three case studies designed to show some of the shortcomings of cost-benefit analyses performed by independent agencies relative to ones conducted in the Executive Branch. These case studies demonstrate the value of embracing Executive Branch models and protocols of cost-benefit analysis.

\section{A. Nuclear Regulatory Commission and the Value of a Statistical Life}

The recent travails of the Nuclear Regulatory Commission (NRC) in updating its value of a statistical life, which has been frozen for two decades, show how cost-benefit valuations suffer when an agency's regulations are not subject to OIRA review. Not only do independent agencies fail to benefit from

113. Press Release, Office of Sen. Rob Portman, Independent Agency Regulatory Analysis Act of 2015, http://www.portman.senate.gov/public/index.cfm/files/serve?File_id=79d546098037-4f87-8873-90aaccb0e120 (citing "OIRA and GAO annual reports" and Report for the Administrative Conference of the United States 87-89 (2013)).

114. OfFice of INFo. AND Regulatory AfFairs, OfFice of MGMT. \& BudGet, REPORT TO CONGRESS ON THE COSTS AND BENEFITS OF FEDERAL REGULATIONS (1997), https://www.whitehouse.gov/omb/inforeg_chap3; OFFICE OF INFO. AND REGULATORY AFFAIRS, OFFICE OF MGMT. \& BUDGET, 2014 REPORT TO CONGRESS ON THE BENEFITS AND COSTS OF FEDERAL REGULATIONS AND UNFUNDED MANDATES ON STATE, LOCAL, AND TRIBAL ENTITIES 2 (2014).

115. See OfFICE OF INFO. \& REgulatory AFFAIRS, OfFICE OF MGMT. \& BUdGeT, 2014 REPORT TO CONGRESS ON THE BENEFITS AND COSTS OF FEDERAL REGULATIONS AND UNFUNDED MANDATES ON STATE, LOCAL, AND TRIBAL ENTITIES 2 (2014).

116. OFFICE OF INFO. \& REgULATORY AFFAIRS, OFFICE OF MGMT. \& BUDGET, 2012 REPORT TO CONGRESS ON THE BENEFITS AND COSTS OF FEDERAL REGULATIONS AND UNFUNDED MANDATES ON STATE, LOCAL, AND TRIBAL ENTITIES 3 (2012).

117. Henry B. Hogue ET Al., CONG. ReSEARCh SERV., R43391, INDEPENDENCE OF FEDERAL FINANCIAL REgulators 1 tbl.1, 11 tbl.2, 13 tbl.3, 18 tbl.4, 28 tbl.5 (2014), https://www.fas.org/sgp/crs/misc/R43391.pdf; Bartlett, supra note 10, at S381 fig.1; see Lisa Schultz Bressman \& Robert B. Thompson, The Future of Agency Independence, 63 VAND. L. REV. 599, 607 (2010) (noting that financial bodies "are among the most prominent independent agencies"). Though still "independent" in name under 44 U.S.C. $\$ 3502(5)$, the CFPB now operates as an executive agency following the severing of Dodd-Frank's provision that the CFPB's single director be removable only for cause. PHH Corp. v. Consumer Fin. Prot. Bureau, 839 F.3d 1 (2016), vacated and rehearing en banc granted, No. 15-1177, 2017 WL 631740 (D.C. Cir. Feb. 16, 2017). 
OIRA's expertise, but they also are isolated from methodological advances by agencies in the Executive Branch.

The Nuclear Regulatory Commission (NRC), like many federal agencies, conducts cost-benefit analysis "as a substantial part of its regulatory analysis." 118 For agencies tasked with the mission of regulating health, safety, and the environment, the number of lives saved-or, stated differently, premature deaths averted - is the biggest benefit of the agencies' actions. This benefit is expressed as the "value of a statistical life" (VSL). So, for example, if a regulation reduces by one in a hundred thousand the risk that an individual in the affected population would die, and the regulation affects five million people, fifty statistical lives are saved as a result of the regulatory action. The lives are described as "statistical" because one cannot ascertain the actual identity of the individuals who would otherwise have died.

The VSL is determined through willingness-to-pay methodologies, under which economists measure "the additional cost that individuals would be willing to bear for improvements in safety (that is, reductions in risks) that, in the aggregate, reduce the expected number of fatalities by one." 119 So, for example, if people are willing to pay $\$ 10$ per year to reduce their annual risk of death by one in one million, the resulting VSL is $\$ 10$ million. ${ }^{120}$

In 1995, NRC pegged its VSL at $\$ 3$ million dollars, correctly describing this value as "consistent with" the Office of Management and Budget's "best estimate and an extensive literature review performed by the NRC." 121 But the NRC's VSL remained unchanged for the past twenty years. In 2010, the Commission began the process of revising this figure, ${ }^{122}$ but it has yet to produce a final updated value. Over this twenty-year span, the NRC became an outlier, using a value that is only roughly a third of that used by the bulk of the federal health and safety agencies. ${ }^{123}$ A stagnant figure over two decades is

118. U.S. GOV'T ACCOUNTABILITY OFFICE, NUCLEAR REGULATORY COMMISSION: NRC NEEDS TO IMPROVE ITS COST ESTIMATES BY INCORPORATING MORE BEST PRACTICE 6 n.9 (2014), http://www.gao.gov/assets/670/667501.pdf.

119. See U.S. DeP'T of TRansp., Guidance on TREatment of the ECONOMIC VALUE OF A STATISTICAL LIFE IN U.S. DEPARTMENT OF TRANSPORTATION ANALYSES 1 (2013).

120. See id.

121. U.S. NuClear REgUlatory COMMISSION, REgulatory ANALYSIS GUIDELINES OF THE U.S. NUCLEAR REgULATORY COMMISSION, NUREG/BR-0058, Rev. 2 at vii; Issuance, Availability, 60 Fed. Reg. 65,694 (Dec. 20, 1995).

122. R. W. BORCHARDT, U.S. NUCLEAR REGULATORY COMM'N, SECY-12-0110, CONSIDERATION OF ECONOMIC CONSEQUENCES WITHIN THE U.S. NuClEAR REgulatory COMMISSION'S REGULATORY FRAMEWORK enclosure 8, at 1 (2012).

123. Cass R. Sunstein, Valuing Life: Humanizing the Regulatory State 94 
particularly problematic because VSL is a function of income, ${ }^{124}$ and is therefore affected by inflation. ${ }^{125}$

In contrast to the NRC, agencies in the Executive Branch exhibit an "increasing consensus" placing their VSLs "in the vicinity of $\$ 9$ million." 26 Absent a difference in the nature of the risks, ${ }^{127}$ such variation is undesirable because it prevents the government from maximizing the number of lives it saves for a given expenditure. ${ }^{128}$ For this reason, John D. Graham, the OIRA Administrator during the presidency of George W. Bush, has been particularly critical of the lack of uniformity in VSLs. ${ }^{129}$

OIRA has never imposed a uniform VSL on Executive Branch agencies, and the respective values do exhibit modest variations. ${ }^{130}$ But even without an express OIRA command, the institution of OIRA review plays a harmonizing function. Michael Livermore explains how the process of OIRA review leads Executive Branch agencies to influence one another. ${ }^{131}$ He maintains that in the application of cost-benefit analysis, agencies "seek guidance from one another and borrow or rely on each other's work."132 Furthermore, agencies can also combine forces to push OIRA toward adopting a technique or perspective or work on opposite sides of an issue "with OIRA performing a mediating role." 133 Regardless of the mechanics of the exchange, "the methodological advances or preferences of one agency can diffuse throughout" the Executive

124. Richard L. Revesz, Environmental Regulation, Cost-Benefit Analysis, and the Discounting of Human Lives, 99 COLUM. L. REV. 914, 962-63 (1999) (noting that "the elasticity of the value of life with respect to earnings ... is approximately one").

125. In that time, per capita income has increased over $75 \%$ in nominal terms, United States Census Bureau, CPS Population and Per Capita Money Income, All Races: 1967 to 2014, Table $P-I$ (last revised Sept. 16, 2015), http://www.census.gov/hhes/www/income/data/historical/people (click on "all races" under table P-1), and one dollar and fifty-six cents of 2015 money replicates the buying power of one 1995 dollar, as calculated by CPI Inflation Calculator, BUREAU OF LABOR STATISTICS, http://www.bls.gov/data/inflation_calculator.htm (last visited Aug. 11, 2015).

126. SUNSTEIN, supra note 123 , at 94 .

127. See Revesz, supra note 124, at $968-71$ (discussing the voluntariness of risk and noting evidence "that individuals assign greater value to avoiding risks that are thrust upon them involuntarily").

128. Tammy O. Tengs \& John D. Graham, The Opportunity Costs of Haphazard Social Investments in Life-Saving, in RISKS, COSTS, AND LIVES SAVED: GeTtING BETTER ResultS FROM REGUlATION 167-68, 177-80 (Robert William Hahn ed., 1996); Tammy O. Tengs et al., FiveHundred Life-Saving Interventions and Their Cost-Effectiveness, 15 RISK ANALYSIS 369, 369-72 (1995).

129. Binyamin Appelbaum, As U.S. Agencies Put More Value on a Life, Businesses Fret, N.Y. TIMES (Feb. 16, 2011), http://www.nytimes.com/2011/02/17/business/economy/ 17regulation.html.

130. REGULATORY IMPACT ANALYSIS: A PRIMER, OFFICE OF INFORMATION AND REGULATORY AFFAIRS 10 (Aug. 15, 2011), https://www.whitehouse.gov/sites/default/files/ omb/inforeg/regpol/circular-a-4_regulatory-impact-analysis-a-primer.pdf (describing "[c]urrent agency practice" for quantifying VSL between "\$5 million to $\$ 9$ million"); SUNSTEIN, supra note 123 , at 94 (noting "agencies ... use a narrow range of $\$ 6$ million to $\$ 9$ million").

131. Michael A. Livermore, Cost-Benefit Analysis and Agency Independence, $81 \mathrm{U}$. CHI. L. REV, 609, 661-66 (2014).

132. Id. at 661 .

133. Id. 
Branch. ${ }^{134}$ In particular, Livermore examines the impact of EPA advances in the quantification of VSL on Department of Transportation, Department of Homeland Security, and Department of Justice rulemakings. ${ }^{135}$

As an independent agency, the NRC is outside the scope of OIRA review and has not been affected by the diffusion of knowledge that has taken place within the Executive Branch. The way it is updating its VSL provides a prime example of the shortcomings of independent agencies with respect to costbenefit analysis.

In 2010, when the NRC embarked on its review project, it enlisted the help of ICF International, a Virginia-based global consulting firm. ${ }^{136}$ After considering ICF's recommendations and examining the VSLs used by other federal agencies, the NRC convened an interagency regulatory analysis workshop in March 2012. ${ }^{137}$ Following the conference, the NRC announced that it expected to issue a final document with its revised VSL in 2014, but that did not happen.

Instead, in August 2015, the NRC issued a draft report proposing to update its VSL measure from $\$ 3$ million to $\$ 9$ million and seeking public comments. ${ }^{138}$ After discussing a number of different approaches to the estimation of VSL, the NRC ultimately arrived at its new estimate of \$9 million for its VSL by averaging the EPA and DOT calculations. ${ }^{139}$ It explained: "Given the extensive resources spent by other Federal agencies on this topic, specifically EPA and DOT, it is prudent for the NRC to leverage these resources and align its VSL recommendations with those of its Federal counterparts." 140 It is not clear when the NRC will respond to the comments it receives and issue a final report. Regardless, NRC's entire internal process was redundant and wasteful considering that it ultimately settled on figures the Executive Branch had previously calculated.

W. Kip Viscusi, the economist who played the most central role developing the VSL, sees no reason for the NRC's long delay, arguing that a VSL update entails "no time-consuming process." 141 He claims that NRC could turn to other agencies that have recently updated their VSLs in order to forgo the legwork of literature review. ${ }^{142}$ NRC Public Affairs Officer Scott Burnell disagrees, arguing that setting a new VSL is a time-intensive process that

134. Id.

135. Id. at 661-66.

136. BORCHARDT, supra note 122 , enclosure 8 , at 1 .

137. See id.

138. U.S. NUCLEAR REGULATORY COMMISSION, REASSESSMENT OF NRC'S DOLLAR

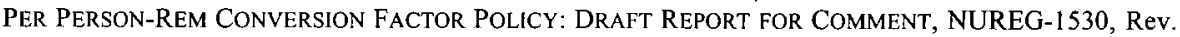
1 , at 18 (2015).

139. Id. at $14-16,18$.

140. Id. at 18 .

141. Davis Burroughs, In Complex Formula, Nuke Regulators Lowball the Value of Human Life, MORNING CONSULT (May 27, 2015).

142. Id. 
requires extensive hypothetical testing. ${ }^{143}$ This claim rings particularly hollow in light of the process used within the Executive Branch to calculate the VSL, dating back to EPA's Guidelines for Preparing Economic Analyses, which were published in $2000 .{ }^{144}$ The EPA relied on the 26 peer reviewed empirical studies available at that time, ${ }^{145}$ five of them authored by Viscusi. ${ }^{146}$ It converted the VSL estimate of each study to constant 1997 dollars and then took the mean of those studies. The resulting value of $\$ 5.8$ million (in 1997 dollars), adjusted for inflation, amounts to the approximately $\$ 9$ million that is now generally used by agencies in the Executive Branch. ${ }^{147}$ In light of this widely accepted methodology, the need for "extensive hypothetical testing" makes little sense. And, in its recently issued draft report, the NRC appears to have finally accepted this view, but not before dedicating time and resources to a question that the Executive Branch had figured out a long time ago.

\section{B. Securities and Exchange Commission and Its Rulemaking Problems}

The SEC's experience provides further support for the proposition that agencies are hampered by not following Executive Branch protocols and practices. Since the early 1990s, the D.C. Circuit has treated SEC regulations with skepticism, particularly in connection with the Commission's cost-benefit analyses. In Timpinaro $v$. SEC, the D.C. Circuit remanded for additional proceedings a rule that defined "professional traders" and prevented them from using an automated trade execution system to "earn riskless trading profits" through arbitrage. ${ }^{148}$ In an opinion by Judge Douglas Ginsburg, a former OIRA Administrator, the court held that "the SEC had not adequately substantiated its reasoning." 149 It remanded the rule for further analysis of its benefits and costs. $^{150}$

The SEC had justified its rule by reasoning that if professional traders were not barred from the automated execution system, "there is a reasonable likelihood that more market makers will cease making markets, spreads will widen and liquidity will be negatively impacted."151 Judge Ginsburg indicated that the SEC should have assessed "how much bid-ask spreads widened" due to professional traders using automated execution systems and whether that

143. Id.

144. U.S. ENVT'L PROTECTION AGENCY, EPA 240-R-00-003, Guidelines FOR PREPARING ECONOMIC ANALYSES 90 (2000). I served on the EPA Science Advisory Board's Environmental Economics Advisory Committee that performed the peer review for this document.

145. Id. at 89 , ex.7-3.

146. Id. (listing five studies that Viscusi authored or co-authored).

147. This calculation can be performed using the Bureau of Labor Statistics' CPI

Inflation Calculator.

148. See 2 F.3d 453, 455 (D.C. Cir. 1993); Bruce Kraus \& Connor Raso, Rational Boundaries for SEC Cost-Benefit Analysis, 30 YALE J. ON REG. 289, 298-99 (2013).

149. Kraus \& Raso, supra note 148, at 299.

150. Timpinaro, 2 F.3d at 458.

151. 56 Fed. Reg. 52,092, 52,096 (Oct. 17, 1991). 
uptick, coupled with the "possibility that market makers would withdraw from some securities," would exceed the rule's benefit of "more timely price changes."152

In 1996, Congress added to the SEC's burdens by enacting the National Securities Markets Improvement Act. It provides that, in promulgating rules, the Commission must "consider, in addition to the protection of investors, whether the action will promote efficiency, competition, and capital formation," "153 giving further statutory support to the SEC's obligation to conduct cost-benefit analyses. Nearly a decade later, the D.C. Circuit struck another blow to SEC rulemaking in U.S. Chamber of Commerce v. SEC. ${ }^{154}$ In that case, the court found that the SEC had not followed the Administrative Procedure Act because of its failure to both "adequately . . . consider the costs mutual funds would incur in order to comply" with a new SEC rule and examine alternatives. ${ }^{155}$ Specifically, Judge Ginsburg, who again wrote the opinion, echoed the dissenting SEC commissioners in expressing concern about two provisions with the potential to impose additional costs on mutual funds, particularly one that increased the required proportion of independent directors for funds without quantifying the costs to the shareholders. ${ }^{156}$ After remand and the SEC's "decision not to modify" the relevant provisions, the U.S. Chamber of Commerce once again challenged them, and the D.C. Circuit vacated the rule. $^{157}$

The SEC's next setback on the cost-benefit front came in American Equity Investment Life Insurance Co. v. SEC, in which the D.C. Circuit vacated a rule interpreting "fixed indexed annuities" under the Securities Act of 1933 because the SEC had "failed to properly consider the effect of the rule upon efficiency, competition, and capital formation." 158 The SEC regulates securities, including "investment contracts," but a statutory exception exists for any security classified as "an 'annuity contract' or 'optional annuity contract' subject to state insurance laws." At issue in the case was the SEC's analysis of Rule $151 \mathrm{~A}$, which interpreted the term "annuity contract" to exclude fixed indexed annuities, a new "hybrid financial product," thus giving purchasers of such products of "the full protection of the federal securities laws." 160 The SEC claimed the rule would establish clarity, encouraging new participants who had previously been wary of the uncertainty surrounding fixed indexed annuities to

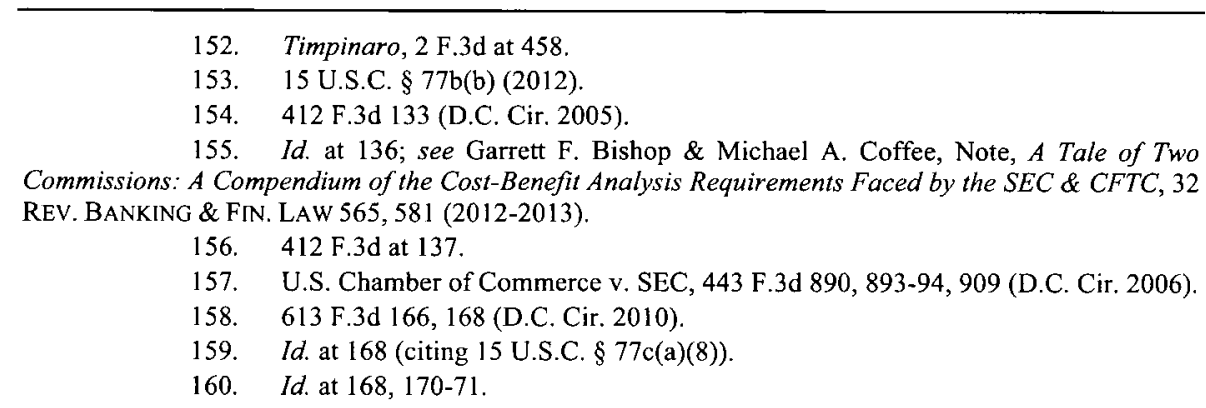


enter the market, thus increasing market competition. ${ }^{161}$ However, the D.C. Circuit balked and determined that the SEC "does not disclose a reasoned basis for its conclusion that Rule 151A would increase competition."162 The D.C. Circuit, in an opinion by Judge Sentelle, rebuked the SEC's "flawed ... analysis," finding it insufficient to demonstrate that the rule would promote competition, efficiency, or capital formation. ${ }^{163}$

A perhaps more significant challenge to an SEC rule came in 2011 in Business Roundtable v. SEC. ${ }^{164}$ In this case, the D.C. Circuit vacated the SEC's Exchange Act Rule 14a-11, which "requires public companies to provide shareholders with information about, and their ability to vote for, shareholdernominated candidates for the board of directors." 165 The court objected to the SEC's failure to sufficiently consider the requirements of the 1996 statutory amendment. ${ }^{166}$ In promulgating the rule, the SEC had pitted a number of difficult-to-quantify benefits like addressing free-riding and collective action problems against amorphous costs like potentially "distracting management" or hurting corporate performance. ${ }^{167}$ The Commission had concluded that the rule would have a positive efficiency impact and therefore that the benefits exceeded the costs. ${ }^{168}$ Judge Ginsburg, who wrote the court's opinion, was again skeptical of the cost-benefit analysis, claiming that "the Commission inconsistently and opportunistically framed the costs and benefits of the rule; failed adequately to quantify the certain costs or to explain why those costs could not be quantified; neglected to support its predictive judgments; contradicted itself; and failed to respond to substantial problems raised by commenters." 169

In this bleak landscape, there were some bright spots for the SEC. As Coates points out, following the D.C. Circuit's decisions, like Business Roundtable, requiring the SEC "to quantify the costs and benefits of its proposed rules," the U.S. District Court for the District of Columbia "subsequently held that such quantification is not mandatory, at least when the SEC is required by statute to adopt a rule, and the benefits sought to be achieved are humanitarian and not economic in nature," $" 170$ and the D.C. Circuit affirmed on that point. ${ }^{171}$ This qualification came with regard to a case centered

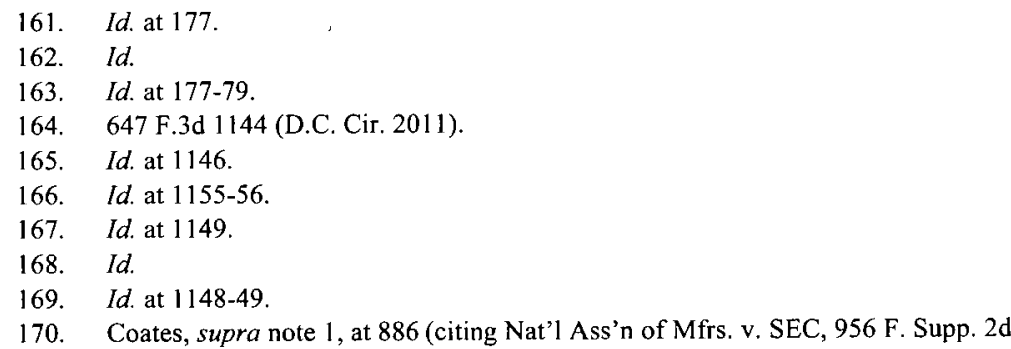
43 (D.D.C. 2013), aff'd in part, 748 F.3d 359 (D.C. Cir. 2014)).

171. 748 F.3d at 369 (finding "reasonable" the SEC's determination that Congress sought to achieve social benefits and subsequent decision not to quantify the rule's benefits). 
on the SEC's "Conflict Minerals Rule,"172 which regulates the trafficking of minerals from the Democratic Republic of Congo. The court found that the proceeds of these transactions helped "to finance conflict characterized by extreme levels of violence ... particularly sexual- and gender-based violence, and contribut[ed] to an emergency humanitarian situation." ${ }^{173}$ Still, this line of cases, particularly the SEC's 2011 defeat in Business Roundtable, generally stands for the proposition that the SEC and other financial regulators face "a very high bar for economic analysis in rulemaking." 174

Following its multiple judicial setbacks, though prior to Business Roundtable, the SEC formed a Division of Risk, Strategy, and Financial Innovation in 2009 "to integrate financial economics and rigorous data analytics into the core mission of the SEC." 175 After Business Roundtable, this division, collaborating with the SEC's Office of General Counsel, updated the SEC's rulemaking guidance. ${ }^{176}$ This document points to court decisions and congressional inquiries as drivers for the effort to improve economic analysis. $^{177}$

The guidance borrows heavily from OMB's Circular A-4, which instructs agencies in the Executive Branch on how they should conduct their cost-benefit analyses. It explicitly points to the Circular along with Executive Orders 12,866 and 13,563 as dictating the "principles" that the SEC should follow, and refers numerous times to these foundational documents. ${ }^{178}$ For example, the SEC identifies four "basic elements of a good regulatory economic analysis" which include:

(1) a statement of the need for the proposed action; (2) the definition of a baseline against which to measure the likely economic consequences of the proposed regulation; (3) the identification of alternative regulatory approaches; and (4) an evaluation of the benefits and costs-both quantitative and qualitative-of the proposed action and the main alternatives identified by the analysis. ${ }^{17}$

172. Conflict Minerals, 77 Fed. Reg. 56,274 (Sept. 12, 2012) (codified at 17 C.F.R. pts. 240.13 p-1 \& 249 b.400).

173. 956 F. Supp. 2d. at 80 (quoting Dodd-Frank $§ 1502(a)$ ); see Schwartz \& Nelson, supra note 105, at 293 ("A full quantification of costs and benefits of the Conflict Minerals Rule would have required the SEC to put a monetary value on preventing rape in the Congo.").

174. Kraus \& Raso, supra note 148, at 290.

175. Economic and Risk Analysis: About the Division, U.S. SEC. \& EXCH. COMM'N, http://www.sec.gov/dera (last updated Jan. 17, 2017).

176. See id. at 621-22; Schwartz \& Nelson, supra note 105, at 298-99.

177. U.S. SEC. \& EXCH. COMM'N, CURRENT GUIDANCE ON ECONOMIC ANALYSIS IN SEC Rulemakings 1 (Mar. 16, 2012) [hereinafter SEC GuIDANCE]; see Catherine M. Sharkey, State Farm "With Teeth": Heightened Judicial Review in the Absence of Executive Oversight, 89 N.Y.U. L. REV. 1589, 1632 (2014); Joshua T. White, Quantified Cost-Benefit Analysis at the SEC, 2(1) ADMIN. L. REV. ACCORD 53, 56-58 (2016).

178. SEC GUIDANCE, supra note 177 , at 3-4.

179. Id. at 4 . 
Similarly, Circular A-4, which at the time had been in effect for thirteen years, provides, almost identically:

A good regulatory analysis should include the following three basic elements: (1) a statement of the need for the proposed action, (2) an examination of alternative approaches, and (3) an evaluation of the benefits and costs-quantitative and qualitative - of the proposed action and the main alternatives identified by the analysis. ${ }^{180}$

The Circular adds that it is necessary to "[i]dentify a baseline" to properly assess costs and benefits. ${ }^{181}$

As the SEC's guidance delves into each element in slightly more detail, the parallels continue. For example, the SEC discusses how rules will often be promulgated to address market failures such as "market power, externalities, principal-agent problems ... and asymmetric information," 182 while Circular A-4 lists "externality, market power, and inadequate or asymmetric information" as typical market failures a rule may seek to address. ${ }^{183}$ Regarding alternatives to the proposed measure, the SEC quotes Circular A-4's advice verbatim that " $[\mathrm{t}]$ he number and choice of alternatives selected for detailed analysis is a matter of judgment" and "[t]here must be some balance between thoroughness and the practical limits on your analytical capacity." 184

Beyond copying Executive Branch guidelines, the SEC also invested in additional economic expertise to carry out the more sophisticated analyses. For example, the Division of Risk, Strategy, and Financial Innovation hired sixteen full-time Ph.D. economists in 2012 alone. ${ }^{185}$ Today, the SEC website lists ninety-four economists within the Division of Economic and Risk Analysis. ${ }^{186}$ At the same time, the role of economists became better integrated, as the Commission added an "Economic Analysis" section to the preamble of its rules, rather than having it appear in scattered sections, thereby lacking a coherent focus. ${ }^{187}$

\footnotetext{
180. CIRCULAR A-4, supra note 8 , at 2 .

181. Id.

182. SEC GUIDANCE, supra note 177 , at 5 .

183. CIRCULAR A-4, supra note 8 , at 4 .

184. SEC GUIDANCE, supra note 177 , at 9 (quoting CIRCULAR A-4, supra note 8 , at

7).

185. OFFICE OF INSPECTOR GENERAL, U.S. SEC. \& EXCH. COMM'N, IMPLEMENTATION of THE CURRENT GUIDANCE ON ECONOMIC ANALYSIS IN SEC RULEMAKINGS, OfFICE OF INSPECTOR GENERAL 12 (June 6, 2013); see also Jennifer Nou, Intra-Agency Coordination, 129 HARV. L. REV. 421, 426 (2015) (discussing the addition of economists to the Division of Risk, Strategy, and Financial Innovation in the wake of Business Roundtable).

186. Economists, U.S. SEC. \& EXCH. COMM'N (last modified Jan. 26, 2017), http://www.sec.gov/dera/economists.
}

187. Kraus \& Raso, supra note 148 , at $325-27$. 
The results appear to have been positive. ${ }^{188}$ For example, the Committee on Capital Markets Regulation referred to the SEC's voluminous 2013 proposed rule on cross-border security-based activities ${ }^{189}$ as "[a] candidate for the 'gold standard' of cost-benefit analysis in the United States." ${ }^{\text {"190 }}$ Similarly, the Center for Capital Markets Competitiveness, "recommend[s] that all financial services regulators should follow similar protocols [to those] found in the SEC guidance memorandum and apply rigorous cost-benefit analysis to improve rulemaking and put in place more effective regulations." $" 191$

These favorable assessments of the changes in the SEC's cost-benefit practices once it started following the protocols used in the Executive Branch are, to some extent, evidence of success. But they also suggest that the SEC's prior rules might well have fared better if these improvements had been implemented decades earlier.

\section{Commodity Futures Trading Commission and Its Methodological Rescue}

The CFTC has likewise encountered problems by not following the Executive Branch's approach to cost-benefit analysis. It eventually acknowledged its shortcomings in this regard by entering into a Memorandum of Understanding (MOU) with OIRA. ${ }^{192}$

The CFTC's efforts to meet its statutory mandates have faced extensive resistance from industry groups ${ }^{193}$ and concern from lawmakers, commentators, internal stakeholders, and others. ${ }^{194}$ Much of this friction stems from the

188. However, some remain skeptical, for example criticizing the SEC's recent cost estimate for a rule, Conflict Minerals, 77 Fed. Reg. 56,274 (Sept. 12, 2012) (codified at 17 C.F.R. pts. 204.13 p-1 \& 249b.400), concerning minerals from conflict areas as "arbitrary, contrived, unscientific, and misleading." Schwartz \& Nelson, supra note 105 , at 327 ; see White, supra note 177 , at 77 (analyzing the SEC's Conflict Minerals Rule cost-benefit analysis and finding the SEC's estimate of the costs of compliance as "overstated").

189. Cross-Border Security-Based Swap Activities; Re-Proposal of Regulation SBSR and Certain Rules and Forms Relating to the Registration of Security-Based Swap Dealers and Major Security-Based Swap Participants, 78 Fed. Reg. 30,968 (May 23, 2013).

190. COMmitTeE on Capital MKTS. Reg., A BalanCed APPROACH to CostBENEFIT ANALYSIS REFORM 13 (2013).

191. ROSE \& WALKER, supra note 5, at v. Still, other commentators maintain that the SEC has much room for improvement. See White, supra note 177 , at 73,76 (calling for improved transparency in SEC cost-benefit analysis and the increased use of retrospective analysis).

192. Memorandum of Understanding between Office of Info. \& Reg. Aff. and U.S. Commodity Futures Trading Comm'n (May 9, 2012), http://obamawhitehouse.archives.gov/sites/default/ files/omb/inforeg/regpol/oira_cftc_mou_2012.pdf [hereinafter CFTC MOU].

193. See Jamila Trindle, CFTC Taps Help for Cost Analysis on New Rules, WaLL ST. J. (May 10, 2012, 1:58 P.M.), http://www.wsj.com/articles/SB1000142405270230407030457739619265 3277890 .

194. See, e.g., Hearing Before the Subcomm. on TARP, Fin. Servs., and Bailouts of Pub. \& Private Programs of the H. Comm. On Oversight and Gov. Reform, 112th Cong. (Apr, 17, 2012) (testimony of Jacqueline C. McCabe) [hereinafter McCabe]; OFFICE OF THE INSPECTOR GENERAL, COMMODity Futures TRAding COMM'N., A Review of COST-BENEFIT ANALYSES PERFormed By THE COMMODITY FUTURES TRADING COMMISSION IN CONNECTION WITH RULEMAKINGS UNDERTAKEN PURSUANT TO THE DODD-FRANK ACT 27-28 (2011), http://www.cftc.gov/ucm/groups/ public/@aboutcftc/documents/file/oig_investigation_061311.pdf (articulating.concerns with the CFTC's 
CFTC's attempts to fulfill a requirement in its organic statute that "[b]efore promulgating a regulation ... the Commission shall consider the costs and benefits of the action." 195 Dodd-Frank added significantly to the regulatory burdens of the CFTC, ${ }^{196}$ which had relatively little expertise in cost-benefit analysis at the time. ${ }^{197}$ Furthermore, the CFTC bears the responsibility of trying "to regulate the swaps industry," which "has historically never been regulated." 198

The CFTC saw its cost-benefit analyses questioned in two significant challenges to important Dodd-Frank rulemakings. ${ }^{199}$ The first was brought by the International Swaps and Derivatives Association and the Securities Industry and Financial Markets Association, which challenged the CFTC's rule on position limits. ${ }^{200}$ The chief complaint was that the CFTC had "neglected to do an adequate cost-benefit analysis of the rule." ${ }^{201}$ However, the D.C. Circuit invalidated the rule on other grounds, without considering the adequacy of the cost-benefit analysis. ${ }^{202}$

In a later case, the Investment Company Institute and the U.S. Chamber of Commerce challenged CFTC rules forcing registration of mutual funds. The district court found the "CFTC fulfilled its responsibilities under both the CEA and APA to evaluate the costs and benefits of the Final Rule." 203 The D.C. Circuit likewise held that the "CFTC's consideration and evaluation of the rule's costs and benefits was not arbitrary or capricious." 204

Even though neither case resulted in having a CFTC rule set aside for an inadequate cost-benefit analysis, the cases highlighted the Commission's potential vulnerabilities. In this connection, commentators criticized its lack of cost-benefit expertise. For example, in testimony before a House subcommittee, Jacqueline McCabe, Executive Director for Research for the Committee on Capital Markets Regulation, a group composed of academics and industry members, worried that flawed cost-benefit analysis would render Dodd-Frank regulations vulnerable "to judicial challenge, prevent important rules from

cost-benefit methodology, but ultimately expressing support for "the cost-benefit discussion"); John D. Graham \& James W. Broughel, Stealth Regulation: Addressing Agency Evasion of OIRA and the Administrative Procedure Act, 1 HARV. J.L. \& PUB. POL'Y 30, 53 (2014).

195. 7 U.S.C. $\$ 19(a)(1)(2012)$.

196. DAVIS POLK, SUMmary OF THE DOdD-Frank WALl STREet REFORM AND CONSUmer Protection ACT, ENACTED InTO LAW ON JULY 21, 2010 ii (2010); see Bishop \& Coffee, supra note 155 , at 566 .

197. See Bishop \& Coffee, supra note 155, at 569-70.

198. Id.

199. See Trindle, supra note 193.

200. Bishop \& Coffee, supra note 155, at 605-06.

201. Michael J. McFarlin, CFTC Sued on Position Limits, FUTURES (Jan. 1, 2012), http://www.futuresmag.com/2012/01/01/cftc-sued-on-position-limits.

202. Int'1 Swaps \& Derivatives Ass'n v. CFTC, 884 F. Supp. 2d 259, 284 (D.D.C. 2012).

203. Inv. Co. Inst. v. CFTC, 891 F. Supp. 2d 162, 190 (D.D.C. 2012), aff'd, 720 F.3d 370 (D.C. Cir. 2013).

204. Inv. Co. Inst., 720 F.3d at 380 . 
taking effect, and contribute to uncertainty in our markets over their fate."205 In particular, McCabe criticized specific cost-benefit assessments, such as the CFTC's "absurd contention" that its Derivatives Clearing Organization General Provisions and Core Principles rule would have "averted the entire [financial] crisis," and therefore that "lost output ... [of] between $\$ 60$ trillion and $\$ 200$ trillion" should be included in the cost-benefit inquiry. ${ }^{206}$

Others, such as Bishop and Coffee writing in the Review of Banking \& Financial Law, have also taken issue with the CFTC's cost-benefit analyses. They discuss the vulnerabilities that the CFTC faces in this area and warn that "Congress failed to consider the effect that applicable cost-benefit analysis requirements will have on the long-term viability and legitimacy of the new Dodd-Frank rules." 207

The Commission itself shared the concern about how its future DoddFrank rules might fare. In this connection, Commissioner Scott O'Malia requested that OMB review the cost-benefit analysis for the CFTC's "Internal Business Conduct Rules," promulgated in February 2012. ${ }^{208}$ In a letter to OMB Acting Director Jeffrey Zients, O'Malia expressed "concern that the Commission's cost-benefit analysis has failed to comply with the standards for regulatory review" dictated to executive agencies by $\mathrm{OMB}$ and the White House. $^{209}$ O'Malia argued that the CFTC process fell short of Executive review requirements and guidelines as "outlined in OMB Circular A-4, Executive Order 12,866, and President Obama's Executive Orders 13,563 and 13,579.,"210 In particular, he claimed that the Commission had "failed to ... identify a clear baseline against which" to gauge "costs and benefits and the range of alternatives under consideration."211 OMB declined to review the analysis, citing the CFTC's status as an independent agency. ${ }^{212}$

One might attribute Commissioner O'Malia's call for OMB review to a political disagreement with the CFTC's Democratic majority, ${ }^{213}$ particularly since it echoed similar arguments by industry groups typically opposed to

205. McCabe, supra note 194.

206. Id. Others have warned that judicial perceptions of the shortcomings of CFTC cost-benefit analysis pose a risk to the "long-term viability and legitimacy" of rules implementing DoddFrank. See Bishop \& Coffee, supra note 155, at 567.

207. Bishop \& Coffee, supra note 155 , at 567.

208. Letter from Scott O'Malia, Comm'r, U.S. Commodity Futures Trading Comm'n., to Jeffrey Zients, Acting Dir., Office of Mgmt. \& Budget (Feb. 23, 2012), http://www.cftc.gov' ucm/groups/public/@newsroom/documents/file/omalialetter022312.pdf.

209. Id.

210. Id.

211. Id.

212. See Trindle, supra note 193.

213. At the time of O'Malia's letter, three of the CFTC's five commissioners had been appointed by President Obama. 
financial regulation, including the U.S. Chamber of Commerce. ${ }^{214}$ But around the same time, the Commission itself negotiated a Memorandum of Understanding (MOU) with OIRA, which was signed in May 2012. ${ }^{215}$ The agreement's main purpose is to bolster the CFTC's "consideration of the costs and benefits of proposed and final rules" in exercising the statutory grants of rulemaking authority under Dodd-Frank. The document provides that the CFTC's cost-benefit policy is to be "informed by OIRA's guidance . . . as well as the best practices of other federal agencies, to the extent permitted by law." 216

The agreement "allow[s] an OIRA staffer to work with the CFTC on the economic analysis of rule making." 217 However, the MOU offers little specific information on the magnitude of OIRA's overall help, describing it in vague terms as "technical assistance ... during the implementation of [Dodd-Frank], particularly with respect to the consideration of the costs and benefits of proposed and final rules." ${ }^{, 18}$ OIRA, however, did not undertake to engage in a supervisory relationship by reviewing the CFTC's cost-benefit analyses. ${ }^{219}$

The existence of an MOU between OIRA and an independent agency is very uncommon. The only other arrangement of this sort was an agreement between OIRA and the Office of Advocacy of the Small Business Administration "for sharing information and providing training for regulatory agencies on compliance with the Regulatory Flexibility Act."220 This agreement, entered into in 2002 , had a duration of three years and was not renewed. $^{221}$

Only one challenge to a CFTC rulemaking has been litigated since the MOU took effect. In September 2014, the Securities Industry and Financial Markets Association joined with the International Swaps and Derivatives Association and Institute of International Bankers to challenge "over a dozen regulations," promulgated between 2011 and 2013, stemming from DoddFrank's provisions governing derivative swaps, including the "extraterritorial application" of such rules, which was promulgated in July 2012 shortly after

214. See Letter from American Farm Bureau Federation et al. to Jeffrey Zients, Acting Dir., Office of Mgmt. \& Budget (Mar. 23, 2012), http://www.centerforcapitalmarkets.com/wpcontent/uploads/2010/04/2012-3.23-CMC-Letter-to-OMB-on-CFTC-Cost-Benefit-Analysis-Final.pdf.

215. CFTC MOU, supra note 192.

216. Id.

217. Trindle, supra note 193

218. CFTC MOU, supra note 192.

219. Id.

220. Memorandum of Understanding between Office of Info. \& Reg. Aff. and Office of Advocacy, U.S. Small Bus. Admin. (Mar. 19, 2002), https://www.sba.gov/sites/default/files/advocacy/ MOU OIRA.pdf.

221. Id.; Sam Kim, New Small Business Program Will Influence Agency Regulatory Reviews, CENTER FOR EFFECTIVE GOVERNMENT (Sept. 11, 2007), http://www.foreffectivegov.org/ node/3419. 
the MOU's signing. ${ }^{222}$ While the CFTC prevailed on certain regulations, the trade groups won summary judgment on other rules, which were subsequently remanded to the CFTC "for its consideration of the costs and benefits of their extraterritorial applications." Ultimately, the CFTC prevailed on some rules and lost on others. ${ }^{223}$

The U.S. District Court for the District of Columbia was critical of the CFTC's cost-benefit failures in promulgating the rules at stake in the case, agreeing with "the plaintiffs that the CFTC was required but failed to consider adequately the costs and benefits ... by excluding from its analyses consideration of the costs and benefits of those Rules' extraterritorial applications." "224 Noting that the CFTC is statutorily required to only "consider" and "evaluate" costs rather than limit rules to those of minimal cost, the district court concluded that "[a]s cost-benefit analysis requirements go, Section 19(a) [of the Commodity Exchange Act] is not particularly demanding." 225 Further qualifying this low standard, the district court pointed out "the CFTC need not even gather additional market data or conduct empirical studies to support its analysis," provided "it reasonably addresses the uncertainty stemming from any data limitations." 226 Yet, against these relatively "flexible requirements," the CFTC still fell short, "fail[ing] to acknowledge, let alone 'consider' and 'evaluate,' the costs and benefits of those Rules' extraterritorial applications." 227

The Committee on Capital Markets Regulation performed a study of CFTC rulemaking by comparing the cost-benefit analyses conducted on proposed and final CFTC rules from before and after the MOU. The Committee concluded that the CFTC has increased its use of quantitative analysis after OIRA began providing technical support, and that "the length, detail, and quality of the analysis have improved to a degree."228 Furthermore, the Committee reported that the proportion of post-MOU rules including quantitative cost-benefit analysis is more than double (up to $69.6 \%$ from $34.2 \%$ ) of what it was prior to the MOU. ${ }^{229}$ The Committee also noted that the CFTC had ceased issuing rules with no cost-benefit analysis whatsoever and had halved the proportion promulgated with non-quantitative analysis. ${ }^{230}$

This study, however, should not be viewed as a definitive assessment of the success of the collaboration between the CFTC and OIRA, in part because

222. Sec. Indus. \& Fin. Mkts. Ass'n v. United States CFTC, 67 F. Supp. 3d 373, 384, 390, 437-38 (D.D.C. Sept. 16, 2014).

223. Id. at $385,437-48$.

224. Id. at 430 .

225. Id.

226. Id. at 431 .

227. Id.

228. COMMITTEE ON CAPITAL MKTS. REG., supra note 190, at i, 8 .

229. Id. at 9 .

230. Id. 
of methodological shortcomings. In particular, it uses the date of the MOU as a strict delineation point, comparing rules prior to the $\mathrm{MOU}$ with rules subsequent to the agreement. This binary categorization ignores the possibilities that OIRA began lending assistance while the MOU was still being negotiated, or that some rules promulgated after the MOU might have been in close to final form before OIRA's assistance became available and might thus reflect an improvement in the CFTC's cost-benefit capabilities before it could begin to benefit from OIRA's influence. A more definitive conclusion will require further analysis.

\section{Toward an Institutional Transformation}

The transformation of the institutional frameworks for financial regulation holds the promise of improving the quality of cost-benefit analysis. Three approaches appear particularly promising, and for each the Executive Branch offers useful models. First, the FSOC should evolve to fulfill its statutory mandate and act as a coordinating body for financial regulatory agencies. Second, OIRA review should be extended to independent financial regulatory agencies. Third, the financial regulatory agencies should take steps to improve their internal economics capacities, using EPA's experience as a model. These proposals-taken individually or, preferably, in tandem-can catalyze an improvement in the economic analysis of financial regulation.

\section{A. Empowering the Financial Stability Oversight Council}

At present, the FSOC operates functionally as a subsidiary of the Treasury Department. $^{231}$ However, the FSOC has the potential to change the landscape of financial regulation by taking charge of coordinating and harmonizing financial regulatory efforts from a systemic viewpoint. In pursuing that end state, the FSOC could be poised to become a center of regulatory analysis excellence and hub of quantification knowledge and data within the financial regulatory sphere.

In essence, what the financial regulatory agencies need to do in their costbenefit analyses is to determine how a particular rule reduces the probability of a serious negative consequence to the economy. ${ }^{232}$ The problem, though, is that individual agencies such as the SEC and the CFTC do not have-and probably could not practically have-sufficient expertise to make these assessments because they do not have a macroeconomic jurisdiction. The FSOC has great

231. Indeed, the FSOC is funded through Treasury, see infra text accompanying notes 259-260, and the Treasury Secretary chairs FSOC, Dodd-Frank $\S 111(\mathrm{a})(1)(\mathrm{A})$, and has offered testimony to Congress on the Council's behalf, see Hearing on the 2014 Annual Report of the Financial Stability Oversight Council Before the H. Fin. Servs. Comm., 113th Cong. 2 (June 24, 2014), https://www.treasury.gov/press-center/press-releases/Pages/j12439.aspx (statement of Secretary Jacob J. Lew). The FSOC has issued few rules and made a modest effort to coordinate financial regulators.

232. See Posner \& Weyl, supra note 2, at 248. 
promise for improving the cost-benefit analyses of the financial regulatory agencies because it is composed of the senior officials within the federal government with responsibility over the stability of the economy, particularly the Secretary of the Treasury and the Chair of the Federal Reserve. Its members (and their respective departments) bring to the table expertise in this area that the individual regulatory agencies could not possibly have independently. ${ }^{233} \mathrm{By}$ virtue of its composition and mandate, the FSOC is fundamentally better positioned to analyze and mitigate systemic risk. ${ }^{234}$ Moreover, the FSOC's explicit mandate to coordinate the work of these agencies provides it with an opening to perform this function. ${ }^{235}$ Unfortunately, that has not yet happened. The experience of the Interagency Working Group that determined the social cost of carbon-the quantified damage of the harm of a ton of carbon dioxide emissions-is instructive and provides a good model for the FSOC to emulate.

Dodd-Frank created the FSOC, originally suggested in a Department of Treasury Financial Regulatory Reform Proposal in 2009, to fulfill three primary purposes: first, "to identify risks to the financial stability of the United States," especially those posed by "large, interconnected bank holding companies or nonbank financial companies"; second, "to promote market discipline"; and finally, "to respond to emerging threats to the stability of the United States financial system.",236 The FSOC was designed to act as "a consultative council" across the Dodd-Frank regulatory landscape. ${ }^{237}$

The FSOC has ten voting members: the Secretary of the Treasury, the Chair of the Federal Reserve, the Comptroller of the Currency, the Director of the CFPB, the Chair of the SEC, the Chair of the CFTC, the Director of the FHFA, the Chair of the NCUA, and "an independent member appointed by the President ... having insurance expertise." ${ }^{238}$ The FSOC's primary concern is with systemic risk. Though Dodd-Frank does not define "systemic risk" or "financial stability,"239 the FSOC's inaugural report portrays "a stable financial

233. See Gersen, supra note 17 , at $693-701$

234. See id.

235. See Catherine M. Sharkey, Agency Coordination in Consumer Protection, 2013 U. ChI. LeGAL F. 329, 351 (2013).

236. Dodd-Frank $\S 112(a)(1)$; U.S. Gov'T ACCOUNTABILITY OFFICE, GAO-09-739,

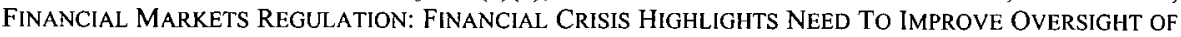
LEVERAGE AT FINANCIAL INSTITUTIONS AND ACROSS SYSTEM 68 (2009), http://www.gao.gov/assets/300/292757.pdf.

237. Edward V. MurPhy, Cong. ResearCh SERV., R42083, Financial Stability OVERSight COUNCIL: A FramewORK TO Mitigate SySTEMIC Risk 2 (2013), http://www.fas.org/sgp/crs/misc/R42083.pdf.

238. Dodd-Frank $\S 111$ (b)(1); see MURPHY supra note 237, at 1; Gersen, supra note 17, at 693. Non-voting members of the FSOC include: the Directors of the Office of Financial Research and the Federal Insurance Office, both Dodd-Frank creations within the Department of Treasury, and a state insurance commissioner, banking supervisor, and securities commissioner, each chosen by their respective peers for two-year terms. Dodd-Frank $\S \S 111(\mathrm{~b})(2), 111(\mathrm{c})(1), 152(\mathrm{a}), 502(\mathrm{a})$; see MURPHY supra note 237 , at 1 ; Gersen, supra note 17 , at 693 .

239. MURPHY, supra note 237 , at 5. 
system" as one that is neither "the source of, nor amplif[ies] the impact of, shocks. $" 240$

To perform its mission to protect against systemic risk, the FSOC received significant regulatory authority. Among the most significant duties the FSOC discharges is the ability to designate "nonbank financial companies" as systemically important. ${ }^{241}$ Dodd-Frank provides that the FSOC may determine such an entity "could pose a threat to the financial stability of the United States" and thereby require it to register with the Federal Reserve and be subject to enhanced regulatory requirements. ${ }^{242}$

The FSOC may also make recommendations to the Federal Reserve regarding restrictions imposed on nonbank financial firms and "large, interconnected bank holding companies." 243 Under this provision, the FSOC can recommend changes to a variety of "prudential standards," such as "liquidity requirements," or "short-term debt limits."244 Furthermore, the FSOC can intervene to impose "mitigatory actions" on any institution that threatens "financial stability." limiting financial offerings, or mandating the firm cease specific activity. ${ }^{246}$

Most importantly for the purposes of this Article, the FSOC also has an overarching coordinating and managerial role and jurisdiction to address systemic concerns. ${ }^{247}$ It has mandates to "facilitate information sharing and

240. FINANCIAL STABILITY OVERSIGHT COUNCIL, 2011 ANNUAL REPORT 3 (2011), http://www.treasury.gov/initiatives/fsoc/Documents/FSOCAR2011.pdf.

241. Dodd-Frank $\$ 113$.

242. Id. This provision is subject to various "considerations," mainly the financial criteria of risk, exposure, and regulation that the FSOC weighs; plus, judicial review remains a potential obstacle. $I d$.

243. Id. $\S 112(\mathrm{a})(2)(\mathrm{I})$.

244. Id. $\$ 115(\mathrm{~b})$.

245. Such actions are applicable only to "a bank holding company with total consolidated assets of $\$ 50,000,000,000$ or more, or a nonbank financial company supervised by the Board of Governors." Id. $\$ 121(\mathrm{a})$.

246. Id. $\S 112(\mathrm{a})(2)$.

247. Though the FSOC is the broadest harmonizing body in financial regulation, there exists another cross-agency effort in that space, the President's Working Group on Financial Markets. The Working Group, comprised of the Secretary of the Treasury and Chairmen of the Federal Reserve, the SEC, and the CFTC, is designed to address the issues stemming from the "market decline" of 1987, and has a mandate to "identify and consider" lessons from that event, including those that target the group's goals of "enhancing the integrity, efficiency, orderliness, and competitiveness of our Nation's financial markets and maintaining investor confidence." Exec. Order No. 12,631, 3 C.F.R. § 599 (1988); U.S. GOV'T ACCOUNTABILITY OFFICE, GAO/GGD-00-46, FINANCIAL REGULATORY COORdINATION: THE ROLE AND FUNCTIONING OF THE PREsIDENT'S WORKING GROUP 4 (2000), http://www.gao.gov/assets/230/228743.pdf. However, the Working Group is far from transparent, and among the only public communications it issues are congressionally mandated reports, for example a 2014 study on insuring "terrorism risk." See PRESIDENT'S WORKING GROUP ON FINANCIAL MARKETS, THE LONG-TERM AVAILABILITY AND AFFORDABILITY OF INSURANCE FOR TERRORISM RISK 1 (2014). As one media account from the financial crisis decried, the group, nicknamed the "Plunge Protection Team," does not even maintain a spokesperson or record meeting minutes. Simon Dumenco, Saved by the Cabal!, N.Y. MAG. (Jan. 27, 2008), http://nymag.com/news/intelligencer/43342. The organization's opacity is so pronounced that some of the most extreme and skeptical see it as "a backroom marketrigging cabal for the Establishment." Id. 
coordination among the member [and other] agencies"; to suggest priorities for member agencies; to "identify" potentially perilous "gaps in regulation"; to "identify systemically important financial market utilities and payment, clearing, and settlement activities"; to recommend that member financial regulators impose certain "standards and safeguards"; to comment on an "existing or proposed accounting principle, standard, or procedure"; and to provide a forum for examining changes in markets and regulation and undertaking member dispute-resolution. ${ }^{248}$ To fulfill these mandates, the FSOC operates through committees meant "to promote shared responsibility among the member agencies and to leverage the expertise" within each. ${ }^{249}$ Subjectmatter committees include "Systemic Risk," "Designation of Nonbank Financial Companies," "Designation of Financial Market Utilities," "Heightened Prudential Standards," "Orderly Liquidation," and "Data.,"250 Reaching beyond the FSOC's concrete statutory requirements and formal channels, these committees "can facilitate informal coordination."251

The FSOC is clearly more than a typical agency by design and mandate. The FSOC's structure and mission has earned it labels such as "superagency" and "agency-of-agencies." 252 For instance, the Council's higher-level coordination role in which "it often functions as a regulator of regulators ... overseeing other oversight agencies," 253 is fairly unique. One example of that

17 , at 693-94.

248. Dodd-Frank $\S 112(\mathrm{a})(2)$. For more on the FSOC's duties, see Gersen, supra note

249. U.S. DEPARTMENT OF THE TREASURY, ABOUT FSOC, http://www.treasury.gov/ initiatives/fsoc/about/Pages/default.aspx (click on "What is FSOC's committee structure?") (last updated May 19, 2015).

250. U.S. Gov't ACCOUNTABILITy OfFICE, GAO-12-886, FinANCIAL STABILITY: New COUNCIL AND Research OfFICE SHOUld STRENGTHEN THE ACCOUNTABILITY AND TRANSPARENCY OF THEIR DECISIONS $62-63$ (2012) [hereinafter GAO 12-886].

251. U.S. GOV'T ACCOUNTABILITY OFFICE, GAO-12-151, DODD-FranK ACT REGULATIONS: IMPLEMENTATION COULD BENEFIT FROM ADDITIONAL ANALYSES AND COORDINATION 27 (2011), http://www.gao.gov/assets/590/586210.pdf [hereinafter GAO 12-151].

252. Gersen, supra note 17 , at $693,696-98$. Though atypical, this structure invites comparisons to a select few bodies past and present. Some liken the FSOC to the National Security Council, citing its core of statutorily mandated members and role in "coordinating the policies and functions of the departments and agencies of the Government" pertaining to a discrete policy sphere, national security. 50 U.S.C. $\S 3021$ (a)-(b) (Supp. I 2013); see Brief for Professors of Law and Finance as Amici Curiae Supporting Respondents at 5, MetLife, Inc. v. FSOC, No. 15-45 (D.D.C. filed Jan. 13, 2015), https://clsbluesky.files.wordpress.com/2015/05/20150525-fsoc-brief-as-posted-final-public.pdf. Other commentators liken the FSOC to a second iteration of the "God Squad," the nickname for the Endangered Species Committee, a group senior government officials with significant individual power bases brought together to decide which endangered species survived and which did not. Gersen, supra note 17, at 696-97; Scott Corey Milligan, The God Squad II: An Analysis of the Financial Stability Oversight Council and the Designation of SIFIs 1 (unpublished manuscript) (on file with author). One scholar argues that the FSOC, due to the insulation of its members, is "facially much less subject to any short-term political control" than the original God Squad. Gersen, supra note 17 at 698 . Another commentator contends that, for reasons including "the Secretary of Treasury's veto power" and a lack of "formal adjudication protections" like those the God Squad had, the FSOC is more susceptible to presidential influence. Milligan, supra, at 24-25.

253. Gersen, supra note 17 , at 701 . 
role is that the "FSOC may nullify CFPB regulations that they believe put the banking or financial system at risk."

In discharging its duties, the FSOC is required to report to Congress annually. ${ }^{255}$ As part of this report, Dodd-Frank requires that each voting member sign a statement certifying that "the Council, the Government, and the private sector are taking all reasonable steps to ensure financial stability and to mitigate systemic risk that would negatively affect the economy."256 Members who do not agree are required to prepare a separate statement, ${ }^{257}$ though no FSOC member has ever done so. ${ }^{258}$

The membership of significant financial regulators and a statutory mandate give the FSOC legitimacy, but the Council requires funding and personnel to function effectively. The Office of Financial Research, which sits within the Department of the Treasury, ${ }^{259}$ pays the FSOC's expenses, ${ }^{260}$ and the FSOC "maintains a small, independent staff to provide advice on statutory authorities and obligations, and to manage its document flow, records retention, and public records disclosure." 261 These staffers include "policy experts to help coordinate the work of the committees and ... complex inter-agency rule makings."262 According to the FSOC's 2016 budget, it will employ thirty-six people by the end of the fiscal year, up from twenty-six at the end of $2014 .^{263}$

The FSOC's employees include economists, lawyers, policy professionals, and others. For example, Stephen Ledbetter, Director of Policy, holds a Master's in Public Policy and has served stints at Freddie Mac, Ginnie Mae, and the FDIC. ${ }^{264}$ Director of Operations Mark Stevens worked in operations administration in the financial sector before moving to other jobs at the Department of Treasury. ${ }^{265}$ Deputy Assistant General Counsel Eric Froman

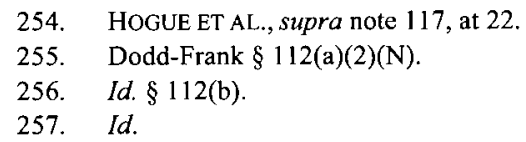

258. See financial Stability Oversight Council, 2011 annual Report 1 (2011); FinANCIAL STABILITY OVERSIGHT COUNCIL, 2012 ANNUAL REPORT 1 (2012); FINANCIAL STABILITY OVERSIGHT COUNCIL, 2013 ANNUAL REPORT 1 (2013); FINANCIAL STABILITY OVERSIGHT COUNCIL, 2014 ANNUAL REPORT 1 (2014); FINANCIAL STABILITY OVERSIGHT COUNCIL, 2015 ANNUAL REPORT 1 (2015); FinANCIAL STABILITY OVERSIGHT COUNCIL, 2016 ANNUAL REPORT 1 (2016), https://www.treasury.gov/initiatives/fsoc/studies-reports/Pages/2016-Annual-Report.aspx.

259. Dodd-Frank § 152(a).

260. Id. $\$ 118$.

261. About FSOC, U.S. DEPARTMENT OF THE TREASURY, http://www.treasury.gov/ initiatives/fsoc/about/Pages/default.aspx (click on "Q: How does FSOC operate?") (last updated May 19, 2015, 4:26 PM).

262. Id.

263. Financial Stability OVERSight COUNCIL, FY 2016 PRESIDENT'S BudGet 6 (2015), http://www.treasury.gov/about/budget-performance/CJ16/21.\%20FSOC $\% 20 \mathrm{FY} \% 202016 \%$ 20CJ.pdf.

264. Stephen Ledbetter, LINKEDIN, http://www.linkedin.com/pub/stephenledbetter/34/61/283 (last visited July 16, 2015).

265. Mark Stevens, LINKEDIN, http://www.linkedin.com/in/marklstevens (last visited July 16,2015$)$. 
spent time in large law firms before moving to serve as an attorney-advisor at Treasury. ${ }^{266}$ Likewise, Charles Cohen, a Ph.D. economist, made the jump from Bain Capital in the private sector to Treasury to serve as Deputy Director of Research at the FSOC. ${ }^{267}$ It appears the FSOC attracts individuals with extensive experience in the financial private sector or government regulation of finance, and often both.

Nonetheless, in a report issued in November 2011, the Government Accountability Office (GAO) found that the FSOC had played a "limited role" in providing coordination among its members, ${ }^{268}$ and that the coordination tools that the FSOC had developed were of "limited usefulness." recommended that the FSOC "establish formal coordination policies" and that "federal financial regulators take steps to better ensure that the specific practices in OMB's regulatory analysis guidance" are a bigger part of rulemakings. ${ }^{270}$ The FSOC broadly agreed with the report's conclusions. ${ }^{271}$

A subsequent GAO report, published in September 2012, once again urged the FSOC "[t]o strengthen accountability and collaboration," including creating "formal collaboration and coordination policies." 272 And, a September 2014 update lamented that the FSOC had not heeded the GAO's suggestions in this regard and found the FSOC's decision to "not adopt practices to coordinate rulemaking across member agencies" to be a mistake. ${ }^{273}$ The FSOC pointed to the lack of statutory authority over such agencies as the reason for failing to "more fully incorporate key practices for successful collaboration," such as coordinating member agency rulemaking timelines, performing "collaborative systemwide stress tests," or forming "external advisory committees."

266. Eric Froman, LINKEDIN, http://www.linkedin.com/pub/eric-froman/0/632/534? trk=pub-pbmap (last visited July 16, 2015).

267. Charles Cohen, LINKEDIN, http://www.linkedin.com/pub/charles-cohen/1/7a5/ 16 ?trk=pub-pbmap (last visited July 16, 2015).

268. GAO 12-151, supra note 251 (referencing "Highlights of GAO-12-151" prior to

“Contents").

269. Id. at 27 .

270. Id. at 39 .

271. Letter from Amias Gerety, Deputy Assistant Secretary, Office of Fin. Stability Oversight Council, to A. Nicole Clowers, Dir., Fin. Mkts. and Cmty. Inv., U.S. Gov't Accountability Office (Oct. 28, 2010), reprinted in GAO-12-151, supra note 251, at 105-06.

272. GAO-12-886, supra note 250, at 55. Similarly, the Bipartisan Policy Center calls for the FSOC to take a role of greater involvement with member agencies, advocating for better "information sharing and coordination," or "assign[ing] each FSOC agency a financial stability objective." BIPARTISAN POLICY Center, FSOC REForm: AN OVERVIEW OF RECENT Proposals 17 (2015), http://bipartisanpolicy.org/wp-content/uploads/2015/01/FSOC-Reform-An-Overview-March2015.pdf. The Bipartisan Policy Center also argues for the execution of "formal cost-benefit analyses" for financial regulation through the FSOC. Id. at 13.

273. U.S. GOV'T ACCOUNTABILITY OFFICE, GAO-14-873T, FINANCIAL STABILITY OVERSIGHT COUNCIL: STATUS OF EFFORTS TO IMPROVE TRANSPARENCY, ACCOUNTABILITY, AND COllaboration (2014) (statement of A. Nicole Clowers, Dir., Fin. Mkts. and Community Inv. Team, before the Subcomm. on Oversight and Investigations of the H. Comm. on Fin. Services) (referencing "Highlights of GAO-14-873-T" prior to page 1) [hereinafter GAO-14-873T].

274. Id. at 13 . 
GAO disagreed, maintaining that the FSOC could respect the autonomy of member agencies and still implement much-needed coordinating practices such as action to address "the lack of clear roles and coordination [that] can lead to duplication, confusion, and regulatory gaps." 275 Additionally, the GAO update criticized the FSOC for failing to form "external advisory committees" despite an exemption designed to promote such activity, ${ }^{276}$ concluding that the FSOC still must "enhance collaboration among its members and with external stakeholders" in order to facilitate its and its members' success. ${ }^{277}$

In contrast to the FSOC's hesitancy, the Interagency Working Group on the Social Cost of Carbon (IWG) is a good example of the potential of interagency collaboration and coordination. The IWG was established " $[\mathrm{t}] \mathrm{o}$ facilitate accounting for the costs of climate impacts, and the benefits of reducing carbon pollution., ${ }^{278}$ The agencies involved include the Council of Economic Advisers, Council on Environmental Quality, Department of Agriculture, Department of Commerce, Department of Energy, Department of Transportation, Environmental Protection Agency, National Economic Council, Office of Management and Budget, Office of Science and Technology Policy, and Department of the Treasury. ${ }^{279}$ The IWG first developed a figure for the social cost of carbon (SCC) in 2009, adopted this value in 2010 following public comment, and issued a revised estimate in $2013 .^{280}$ Since the IWG released its first figure, the SCC estimate had been used, as of July $2015,{ }^{281}$ in thirty-four proposed rulemakings performed by five agencies: the Department of Energy, ${ }^{282}$ the EPA, ${ }^{283}$ the Department of Transportation, ${ }^{284}$ the Department of Agriculture, and the Department of Housing and Urban Development. ${ }^{285}$

275. Id. at 13 (referencing also "Highlights of GAO-14-873T" prior to page 1).

276. Id.

277. Id. at 14.

278. Environmental Defense Fund et al,, Comment Letter on Proposed Rule on Energy Conservation Standards for Walk-in Coolers and Commercial Refrigeration Rules 3 (Nov. 12, 2013), http://policyintegrity.org/documents/Comments_on_use_of_SCC_in_Walk-in_Coolers_and_ Commercial_Refrigeration_Rules.pdf [hereinafter Walk-in Cooler Comment].

279. See InTERAGENCY WORKING GROUP ON SOCIAL COST OF CARBON, U.S. GOV'T, RESPONSE TO COMMENTS: SOCIAL COST OF CARBON FOR REGULATORY IMPACT ANALYSIS UNDER EXECUTIVE ORDER 128661 (2015), http//www.whitehouse.gov/sites/default/files/omb/inforeg/sccresponse-to-comments-final-july-2015.pdf. As this Article was going to press, President Trump disbanded the IWG. See Presidential Executive Order on Promoting Energy Independence and Economic Growth $\S 5(\mathrm{~b})$ (2017).

280. Id. at 2 .

281. Id. at 4 .

282. See Energy Conservation Program: Energy Conservation Standards for Residential Clothes Washers, 77 Fed. Reg. 32,381 (May 31, 2012).

283. See 2017 and Later Model Year Light-Duty Vehicle Greenhouse Gas Emissions and Corporate Average Fuel Economy Standards, 76 Fed. Reg. 74,854 (Dec. 1, 2011).

284. See id. (rule issued jointly with EPA).

285. The Department of Agriculture and Department of Housing and Urban Development jointly issued a notice of final determination using the Social Cost of Carbon. See Final Affordability Determination-Energy Efficiency Standards, 80 Fed. Reg. 25,901 (May 6, 2015). 
The IWG faced the daunting task of estimating the uncertainty of climate change far into the future, which it analyzed through a sophisticated statistical technique known as Monte Carlo analysis. ${ }^{286}$ Such forecasting demands dealing with climate sensitivity, "a metric used to characterize the response of the global climate system to a given forcing ... broadly defined as the equilibrium global mean surface temperature change following a doubling of atmospheric $\mathrm{CO}_{2}$ concentration" ${ }^{287}$; determining the appropriate discount rate, which adjusts the benefits of mitigation actions to account for the passage of time, to use in an intergenerational context; and many other difficult and controversial matters. ${ }^{288}$

The IWG's process for determining an estimate for the SCC and for updating that initial estimate has been consistent, transparent, and open, offering scholars, industry groups and others ample opportunities to comment on its analytic method and decisions. ${ }^{289}$ In 2010 , the IWG published a Technical Support Document that detailed its decision-making process with respect to how it assessed and employed scientific models. ${ }^{290}$ The IWG provided opportunities for public comment, ${ }^{291}$ and further comment opportunities were provided by the respective agencies in their notice-andcomment rulemakings that relied on the SCC. ${ }^{292}$ In response to its most recent solicitation, the IWG received 140 unique sets of comments and over 39,000 form letter submissions, ${ }^{293}$ to which the IWG responded in a forty-four page July 2015 document. ${ }^{294}$ And, recently, the IWG asked the National Academy of Sciences "to review the latest research on modeling the economic aspects of climate change to further inform future revision to the SCC estimates used in regulatory impact analyses.,295

286. Environmental Defense Fund et al., Comments on Petition for Correction: Technical Support Document: Social Cost of Carbon for Regulatory Impact Analysis under Executive Order 12866 (February 2010) and Technical Support Document: Technical Update of the Social Cost of Carbon for Regulatory Impact Analysis under Executive Order 12,866 (May 2013) 5 n.9 (Oct. 21, 2013), http://policyintegrity.org/documents/Policy_Integrity_Comments_OMB_petition.pdf.

287. David A. Randall et al., Climate Models and Their Evaluation, in Climate Change 2007: The Physical Science Basis: Contribution of Working Group I to the Fourth ASSESSMENT REPORT OF THE INTERGOVERNMENTAL PANEL ON CLIMATE CHANGE 629 (Susan Solomon et al. eds., 2007).

288. Walk-in Cooler Comment, supra note 278, at 5-6.

289. See id. at 3-4.

290. Id. at 4 .

291. INTERAGENCY WORKING GROUP ON SOCIAL COST OF CARBON, supra note 279, at 4; Walk-in Cooler Comment, supra note 278, at 4 n.11.

292. Walk-in Cooler Comment, supra note 278, at 4 n.11.

293. INTERAGENCY WORKING GROUP ON SOCIAL COST OF CARBON, supra note 279,

at 4 .

294. See id.

295. Assessing Approaches to Updating the Social Cost of Carbon, THE NAT'L ACADS. OF SCIS., ENG'G \& MED., http://sites.nationalacademies.org/DBASSE/BECS/CurrentProjects/ DBASSE_167526 (last visited Nov. 22, 2015). The report was issued in January 2017. See THE NAT'L ACADS. OF SCIS., ENG'G \& MED., Valuing Climate Damages: Updating Estimation of the SOCIAL COST OF CARBON DIOXIDE (2017). 
The IWG has accomplished a great deal by convening an interagency group to perform the very difficult task of valuing the benefits of carbon dioxide reductions. It explicitly explained its methodology, established a protocol for dealing with uncertainties, and allowed meaningful opportunities for public participation. The IWG should be viewed as a model to which crossagency collaborations should aspire.

In particular, the FSOC should be guided by the IWG's experience in devising a robust collaboration with the financial regulatory agencies and creating an infrastructure to facilitate the preparation of high-quality costbenefit analyses. The FSOC could serve as a clearinghouse for expertise, particularly in diffusing knowledge cultivated in member agencies and brokering synergies between various regulators. ${ }^{296}$ To play this role effectively, it would almost certainly need additional staff, beyond its thirty-six budgeted positions, to bolster its analytical capabilities. ${ }^{297}$ In comparison, the EPA's Office of Policy, which offers crosscutting management and analytical support in addition to special expertise in various subject matter specialisms vital to the agency, ${ }^{298}$ employs roughly 140 full-time equivalents. ${ }^{299}$ The FSOC could also take unilateral steps, for example entering into MOUs with individual financial regulatory agencies, offering to provide a systemic outlook and analytical firepower to the rulemaking process. And, the FSOC could follow the GAO's recommendations and take a more active role as a coordinating body. ${ }^{300}$

296. Others disagree. For example, Alex J. Pollack of the American Enterprise Institute claims that the FSOC is incapable of "fulfill[ing] its assignment from Congress" because "a committee of government employees is constitutionally incapable of criticizing their employer, the government" as a cause of "systemic risk." Alex J. Pollock, FSOC Needs Fixing, AMERICAN (Feb. 21, 2015), https://www.aei.org/publication/fsoc-needs-fixing. He sees little promise in the FSOC playing a centralized coordinating and oversight role in its current state and advocates that Congress should "scrap [the] FSOC and replace it" with a "purely advisory" body "with maximum intellectual power and zero regulatory power." Id.

297. See FINANCIAL StABILITY OVERSIGHT COUNCIL, FY 2016 PRESIDENT'S BUDGET, supra note 263 , at 6.

298. These areas include: "regulatory policy and management, environmental economics, strategic environmental management, sustainable communities, and climate adaption." About the Office of Policy (OP), U.S. ENVTL. PROTECTION AGENCY (last updated Jan. 25, 2017), http://www.epa.gov/aboutepa/about-office-policy-op.

299. U.S. ENVTL. PROTECTION AgENCY, Fiscal YeAR 2016 Justification OF APPROPRIATION ESTIMATES FOR THE COMMITTEE ON APPROPRIATIONS, EPA-190-R-15-001, at 1059 (2015), http://www.epa.gov/sites/production/files/2015-02/documents/epa_fy_2016_congressional_ justification.pdf (reflecting 138.9 full time equivalents for 2015 and proposing 140.9 for fiscal year 2016).

300. GAO-14-873T, supra note 273, at 13-14. For example, the Center for Capital Markets advocates that the FSOC take steps to promote regulatory efficiency as part of its coordinating responsibility including: "[m] onitor and mitigate cumulative impacts of regulation," "[i]dentify and fill regulatory gaps," and "[s]treamline duplicative regulations, reporting, and oversight." CTR. FOR Capital MKts. Competitiveness, Financial. Stability OVERSight COUNCIL Reform AgENDa 4 (2013), http://www.centerforcapitalmarkets.com/wp-content/uploads/2013/08/2013_Financial-StabilityOversight-Council-Reform-Agenda.pdf. 


\section{B. A Role for OIRA}

One alternative to voluntary FSOC review of financial regulatory analysis under the mantle of coordination is to empower OIRA to perform the same function, as it does currently for the Executive Branch agencies. OIRA could perform this review directly with respect to regulatory decisions for which FSOC oversight is not legally required. ${ }^{301}$ However, the viability of this approach is predicated on the assumption that OIRA has the authority to review regulatory analysis by so-called "independent" agencies. Additionally, if FSOC action is statutorily required, as is the case for the Council's own rulemakings, OIRA already has review jurisdiction because FSOC is treated as an Executive Branch agency. ${ }^{302}$ However, as indicated later in this section, ${ }^{303}$ such review has not been effective in past FSOC rulemakings, and more substantive OIRA engagement would be desirable.

Federal regulatory agencies have traditionally been divided into executive and independent categories, based primarily on whether the President can remove the agency head at will or whether the agency head (or heads) is protected by a for-cause removal provision. ${ }^{304}$ Currently, the requirement that OIRA review significant agency rules, and in particular scrutinize the costbenefit analyses supporting such rules, extends only to executive agencies. ${ }^{305}$ The Executive Orders regarding regulatory review exempt independent agencies, including the key financial regulatory agencies like the SEC and the CFTC. ${ }^{306}$ But the fact that no president has chosen to extend OIRA review to independent agencies does not mean that such expansion is unconstitutional or undesirable. ${ }^{307}$

301. See supra text accompanying notes $274-275$.

302. A Dodd-Frank provision adding the CFPB and Office of Financial Research to the list of independent agencies in the Paperwork Reduction Act did not include the FSOC, rendering it an Executive Branch agency. See Dodd-Frank $\S 1100 D(a), 44$ U.S.C. $§ 3502(5)$; Anderson P. Heston, Note, The Flip Side of Removal: Bringing Appointment into the Removal Conversation, 68 N.Y.U. ANN. SURV. AM. L. 85, 99 (2012).

303. See infra text accompanying notes $348-358$.

304. See Kirti Datla \& Richard L. Revesz, Deconstructing Independent Agencies (and Executive Agencies), 98 CORNELL L. Rev. 769, 778-81 (2013); see also PHH Corp. v. Consumer Fin. Prot. Bureau, 839 F.3d 1, 8 (2016), vacated and rehearing en banc granted, No. 15-1177, 2017 WL 631740 (D.C. Cir. Feb. 16, 2017). (invalidating the CFPB's for-cause removal provision and noting that, following the severing of that provision, "[ $t$ ] he CFPB therefore will continue to operate ... but will do so as an executive agency akin to other executive agencies headed by a single person").

305. See Exec. Order No. 12,866, § 6, 3 C.F.R. 638 (1994); Datla \& Revesz, supra note 304 , at 836 .

306. Exec. Order No. 13,563, § 7(a), 3 C.F.R. 3821 (2011); Exec. Order No. 12,866, $\S$ 3(b), 3 C.F.R. 638 (1994); see VIVIAN S. CHU \& DANIEL T. SHEDD, CONG. RESEARCH SERV., R42720, PRESIDENTIAL REVIEW OF INDEPENDENT REGULATORY COMMISSION RULEMAKING: LEGAL ISSUES 2-3, 3 n.23 (2012), https://www,fas.org/sgp/crs/misc/R42720.pdf). Note, however, that the OCC was not exempted from OIRA review prior to the passage of the Dodd-Frank Act. Bartlett, supra note 10, at S381 fig.1.

307. See Rachel E. Barkow, Insulating Agencies: Avoiding Capture Through Institutional Design, 89 TEX. L. REV. 15, 31-32, $32 \mathrm{n} .81$ (2010) (concluding that the constitutionality of such an expansion of OIRA review remains an "open ... question"). 
Kirti Datla and I have argued that "[b]ecause Congress has not by statute insulated the so-called independent agencies from regulatory review, the President can require them to comply with the governing executive orders.",308 Relying on both statutory interpretation and constitutional analysis, we explained why it is inappropriate to imply constraints on presidential control over an agency beyond those specified in the agency's enabling statute. ${ }^{309} \mathrm{We}$ pointed out that agencies exhibit different indicia of independence beyond forcause removal, including specified tenure, multimember status, partisan balance requirements, independent litigation authority, authority to bypass OMB's budget process, and adjudication authority. Many Executive Branch agencies have some indicia of independence, and many independent agencies lack others. ${ }^{310}$ We showed that the world does not neatly divide into a binary scheme. In light of this pattern, and rejecting dicta to the contrary in Humphrey's Executor v. United States, ${ }^{311}$ we argued that one indicia of independence should not be used to imply indicia that Congress did not provide. $^{312}$

Relying on some different grounds, the Office of Legal Counsel (OLC) expressed a congruent view in a February 1981 memorandum to David Stockman, then the Director of OMB. ${ }^{313}$ Though the precise contours of the issue have changed since that 1981 memo due to the Supreme Court's decision to alter the test for removal of "executive officers" in Morrison v. Olson, ${ }^{314}$ the OLC memo continues to provide key legal underpinnings for extending executive review. The document argued that the view of rulemaking as entirely insulated from politics was anachronistic, and it relied on statutory powers granted to the President with regard to independent agencies under the Paperwork Reduction Act and Regulatory Flexibility Act as evidence of the legitimacy of some executive influence, "especially when it consists of a coordinating role with only an indirect effect on substantive policymaking."315 The OLC memorandum also argued that the Constitution's Take Care Clause gave the President the authority to ensure independent agencies faithfully execute the laws, which leaves room "for many types of procedural supervision." 316 The OLC concluded that extending executive review of

308. Datla \& Revesz, supra note 304 , at 837

309. See id. at 773

310. See id. at 772

311. 295 U.S. $602(1935)$

312. See Datla \& Revesz, supra note 304, at 827-32.

313. See Memorandum for the Hon. David Stockman, Director of OMB, from Larry L. Simms, Acting Ass't Atty. Gen., O.L.C. (Feb. 12, 1981), reprinted in Role of OMB in Regulation: Hearing Before the Subcomm. on Oversight and Investigations of the H. Comm. on Energy and Commerce, 97th Cong., 1st Sess. 158-63 (1981) [hereinafter Stockman Memo].

314. 487 U.S. 654 (1988); see Harold H. Bruff, Presidential Management of Agency Rulemaking, 57 GEO. WASH. L. REV. 553, 590-93 (1989).

315. Stockman Memo, supra note 313 , at 160, 162-63, 163 n. 16.

316. Id. at 162 . 
independent agency analysis is permissible under the law and Constitution, provided the likely event that the Supreme Court was open to disclaiming dicta in Humphrey's Executor. ${ }^{317}$

The OLC memorandum did worry about the possibility of a congressional backlash if the President extended OIRA review to independent agencies, ${ }^{318}$ and it is primarily for this reason that no President has invoked that authority, as the Congressional Research Service indicates in a 2012 report. $^{319}$ As thenProfessor Elena Kagan notes, the Reagan Administration "almost certainly exempted the independent agencies because it feared provoking a Democratic Congress, rather than because it believed the law ... required this course of action." 320 Similarly, former OIRA administrator Sally Katzen maintains that the absence of any decision to widen OIRA review was the product of a desire not to "antagoniz[e]" Congress, rather than a decision predicated on any legal objection or uncertainty. ${ }^{321}$

But a number of factors suggest that the political landscape on this issue might be shifting, at least subtly. The introduction by Senators Rob Portman, Mark Warner, and Susan Collins of the Independent Agency Regulatory Analysis Act of $2015,{ }^{322}$ which would extend OIRA review to independent agencies, shows at least some level of bipartisan congressional support for the idea, even if the bill never passes. ${ }^{323}$ Second, this support at least suggests that if the President took this action by Executive Order, an effort to congressionally override it might be stopped by a Senate filibuster, and that even if legislation passed there might not be sufficient votes to overcome a presidential veto.

This bill provided the occasion for six former OIRA Administrators of both parties to advocate for more rigorous cost-benefit mechanisms in such agencies: James C. Miller III (Reagan), Wendy Lee Gramm (Reagan), Sally Katzen (Clinton), John Spotila (Clinton), John D. Graham, (George W. Bush), and Susan Dudley (George W. Bush). ${ }^{324}$ They wrote to the leadership of the

317. Id. at $158-59,163-64$.

318. Id. at $158-59$

319. CHU \& SHEDD, supra note 306, at 12 ("Determinations not to extend the [costbenefit analysis] requirements to the IRCs were apparently due to political rather than legal impediments.").

320. Elena Kagan, Presidential Administration, 114 HaRv. L. REV. 2245, 2278 n.124

(2001).

321. Sally Katzen, Opening Remarks at the Resources for the Future Conference: Can Greater Use of Economic Analysis Improve Regulatory Policy at Independent Regulatory Commissions? 2-3 (Apr. 7, 2011), http://www.rff.org/Documents/Events/Workshops $\% 20$ and $\% 20$ Conferences/1 10407_Regulation_KatzenRemarks.pdf.

322. S. 1607, 114 th Cong. (2015). The same bill was introduced in two previous sessions.

323. See Lydia Wheeler, Watchdogs Cheer Shelved GOP Regulatory Bills, HILL (Aug. 2, 2015); infra text accompanying notes 324-328.

324. Letter from Sally Katzen, former Adm'r, Office of Info. \& Reg. Affairs, et al., to Thomas R. Carper, Chairman, S. Comm. on Homeland Sec. \& Gov't Affairs \& Thomas A. Coburn, Ranking Member, S. Comm. On Homeland Sec. \& Gov't Affairs (June 18, 2013), 
Senate Committee on Homeland Security and Governmental Affairs to decry the shortcomings of rulemaking by independent agencies: "Our concern is that independent regulatory agencies typically do not engage in the economic analysis that has come to be expected from executive agencies." ${ }^{\prime 25}$ The former Administrators claimed that, for 2012, "not one of the 21 major rules issued by [independent] agencies was based on a complete benefit-cost analysis," and advocated for the proposed Act as a means of "affirming the president's authority to extend these agencies the same principles of regulation that have long governed executive agencies." 326

In another letter, former high-ranking officials at independent agenciesincluding two former Acting Chairmen of the CFTC, William P. Albrecht (Clinton) and Sharon Brown-Hruska (George W. Bush) -argued that "the justification for cost-benefit analysis and review applies no less to independent agencies than to executive agencies," in effect urging the application of the White House's "regulatory analysis and review regime" to independent agencies through statutory mandate. ${ }^{327}$ Further, they lamented the lack of analytical transparency from independent agencies, claiming, as had the former OIRA Administrators, that none of the rules such agencies promulgated in 2012 was predicated on "a complete, quantified cost-benefit analysis.",

In June 2015, fourteen "legal scholars in areas of administrative law, regulation, and government" wrote a letter, which I joined, in support of the bill. ${ }^{329}$ The letter underscored that extending OIRA review to independent agencies would benefit "the underlying analysis and ultimate quality of agency regulations." ${ }^{330}$ It also emphasized that such an extension of OIRA's current responsibilities is widely seen as within "the President's authority.",331

The case studies presented in Part I provide significant fodder for the argument that the administrative state would be better off with OIRA review of

http:/www.portman.senate.gov/public/index.cfm/files/serve?File_id=6f3f466c-e744-4d99-892a$91 \mathrm{f} 6 \mathrm{e} 6348 \mathrm{ebf}$.

325. Id.

326. Id

327. Letter from Nancy Nord, former Comm'r. \& Acting Chairman, Consumer Prod. Safety Comm'n., et al, to Thomas R. Carper, Chairman, S. Comm. On Homeland Sec. \& Gov. Aff. \& Thomas A. Coburn, Ranking Member, S. Comm. on Homeland Sec. \& Gov. Aff. (June 18, 2013), http://www.portman.senate.gov/public/index.cfm/files/serve?File_id=8eb0dbd9-5631-4878-bfb2-

e040407cfoba. Joseph Mohorovic, a current Commissioner of the Consumer Product Safety Commission has likewise called for the extension of external OIRA review to independent agencies such as his. Joseph P. Mohorovic, Improving the Process of Making Rules at Independent Agencies, RegBlog (Jan. 9, 2017), http://www.regblog.org/2017/01/09/mohorovic-improving-process-rules-independentagencies.

328. Letter from Nancy Nord to Thomas R. Carper \& Thomas A. Coburn, supra note 327.

329. Letter from Jonathan H. Adler et al, to Ronald H. Johnson, Chairman, S. Comm. on Homeland Sec. \& Gov. Aff. \& Thomas R. Carper, Ranking Member, S. Comm, on Homeland Sec. \& Gov. Aff. (June 17, 2015), http://www.portman.senate.gov/public/index.cfm/files/serve?File_id= 221 f0cae-bde3-4312-baal-ccd754f6b10a.

330. Id.

331. Id. 
the cost-benefit analyses of the financial regulatory agency. The NRC's stalled efforts on VSL, the SEC's adoption, decades late, of the standard approach to performing cost-benefit analysis, and the CFTC's call for an OIRA rescue from its methodological shortcomings are strong evidence that independent agencies are significantly underperforming relative to their counterparts in the Executive Branch. Indeed, in a review of Dodd-Frank implementation, the Government Accountability Office concluded that if financial regulators followed the OIRA approach to cost-benefit analysis, their regulatory decisions would have greater "[t]ransparency and [r]igor." 332

These shortcomings are likely to be magnified by the Supreme Court's decision in Michigan v. EPA. ${ }^{333}$ As discussed above, it is likely that the courts will now impose cost-benefit requirements to a broader set of financial regulations. ${ }^{334}$ And, unless the agencies can improve their performance, their work will be even more vulnerable than it already is.

The potential of OIRA review to improve the regulatory analysis in financial rulemakings provides strong functional support to the structural arguments in favor of OIRA review made earlier in this Section. Prominent commentators explain that functional considerations can play a role in constitutional interpretation. For example, Judge Posner has advocated a "pragmatic approach" that "asks judges to focus on the practical consequences of their decisions." 335 Similarly, in considering the existence and implementation of the political question doctrine, Jesse Choper has advocated for criteria that are primarily "based on functional considerations rather than constitutional language or original understanding." 336 Along similar lines, Erwin Chemerinsky has argued, in the vein of the legal realists of generations past, that "formalistic analysis" in federalism cases is "misguided," favoring instead a "functional" approach. ${ }^{337}$ The argument in favor of OIRA review advanced here need not deal with any tradeoff among different methods of constitutional interpretation because the structural and functional arguments point in the same direction.

In theory, financial regulatory agencies could follow the Executive Branch's directives on the preparation of cost-benefit analyses, such as Circular A-4, without being subjected to OIRA review. But as Ryan Bubb has noted, the institutional role of OIRA review has significant value: "The OIRA model has been a substantial success in other regulatory domains, and there is no reason

\footnotetext{
332. GAO-12-151, supra note 251 , at 14.

333. See supra text accompanying notes 12-16.

334. See supra text accompanying note 16.

335. Richard A. Posner, The Supreme Court, 2004 Term-Foreword: A Political Court, 19 HARV. L. REV. 32, 90 (2005).

336. Jesse H. Choper, The Political Question Doctrine: Suggested Criteria, 54 DuKE. L. J. 1458, 1523 (2005).

337. Erwin Chemerinsky, Formalism and Functionalism in Federalism Analysis, 13 GA. ST. U. L. REV. 959, 969 (1997).
} 
why that model could not be similarly successful in financial regulation." And, as Livermore has indicated, OIRA review allows particular agencies to benefit from the experience of other agencies. ${ }^{339}$

There are opposing views, which object to the application of OIRA review to certain types of agencies. For example, Bruce Kraus and Connor Raso argue that OIRA review of multi-member independent agencies would not be productive. $^{340}$ In their view, "the degree of rationality we expect from hierarchical bureaucracies" constitutes an "unrealistic expectation" for "multimember bi-partisan bodies," like many of the financial regulatory agencies. ${ }^{341}$ As an example, Kraus and Raso catalog the SEC's incompatibility with OIRA review. For example, though SEC staff is responsible to the Chairman, the Commission's other members- even those from the same political party or appointed by the same president - are independent and not bound to support the Chairman's positions. ${ }^{342}$ In this environment, compromise might play an important role because unanimous decisions might be less likely to be challenged in the courts. ${ }^{343}$ They claim that economic analysis, while important to "inform" agency decision making, cannot possibly play the same role in a multimember agency as it does a single-head agency, where "policy options and decisions can flow down and up the chain in an orderly, logical manner, with big decisions made first, informed by cost-benefit analysis." 344

The main problem with this argument, however, is that courts are already requiring cost-benefit analysis, and are likely to move even more decisively in that direction in the future. And, if the independent regulatory agencies would face problems before OIRA because of the need to compromise their decisions, they are likely to face exactly the same problems in the courts, with more serious consequences.

In the current political climate, the enactment of legislation extending the scope of OIRA review is unlikely. Legislative efforts to reform the administrative state have been largely unsuccessful since the defeat of Newt Gingrich's Contract with America following the 1994 elections, ${ }^{345}$ and, if anything, the congressional stalemate is more pronounced that it has been for decades. But for the reasons discussed above, the President might now be able to do so by Executive Order without facing the same level of political backlash

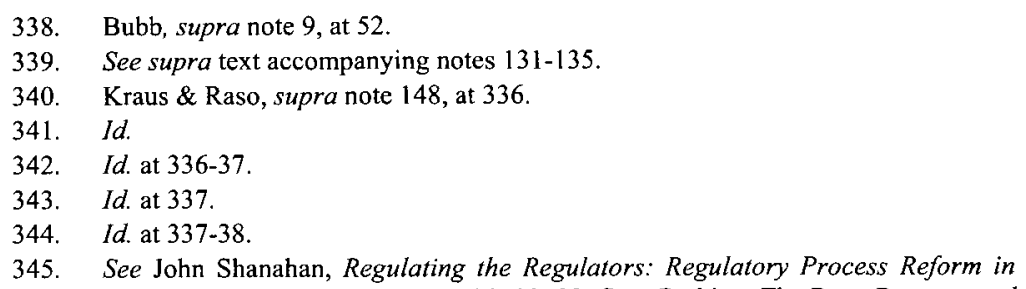
the 104th Congress, Regulation, Winter 1997, at 27, 28-29, 32; Sam Batkins, The Past, Present, and Future of Congress on Regulatory Reform, AMERICAN ACTION FORUM INSIGHTS (May 14, 2015), $\mathrm{http} / /$ www americanactionforum.org/insight/the-past-present-and-future-of-congress-on-regulatoryreform. 
that the Executive Branch has historically feared. And, to blunt some opposition, this Executive Order could make clear that certain actions by the Federal Reserve, where independence is most prized, ${ }^{346}$ would not be subject to presidential oversight. ${ }^{347}$

So far the discussion in this Section has focused on OIRA review of regulations by financial agencies in instances in which the FSOC does not play a coordinating role. Situations in which the FSOC has played a voluntary coordinating role give rise to further considerations. In particular, should the FSOC review be followed by OIRA review? Would such an arrangement be desirable $?^{348}$ On the one hand, it would give OIRA the opportunity to diffuse its expertise and harmonize cost-benefit methodologies across a broader set of agencies. On the other hand, duplicate review might lead to needless cost and delay.

Ultimately, the best approach might be to use OIRA to help build up the FSOC's cost-benefit expertise. Under this scenario, the more robust the FSOC's review grows, the less necessary OIRA review becomes. If this process is successful, the FSOC will eventually be able to unilaterally provide sufficient coordination and oversight for financial rulemaking. As such, OIRA review of FSOC coordinating actions might become superfluous. At that time, the Executive Order on cost-benefit analysis could be amended to exempt regulatory analysis conducted by the FSOC from OIRA review, leaving the FSOC alone as the oversight and coordinating body for financial rulemaking.

In addition to its coordinating role, the FSOC has certain regulatory responsibilities under Dodd-Frank. Because the FSOC is an Executive Branch

346. See Datla \& Revesz, supra note 304 , at 841.

347. Although extension of OIRA review of cost-benefit analysis to independent agencies is desirable, it may not be quite as simple as signing a new Executive Order. The complexities that OIRA review of the SEC would entail are emblematic of potential concerns that must be mitigated in the process of expanding OIRA review. For example, Professor Yoon-Ho Alex Lee argues that the "efficiency-criterion" for cost-benefit analysis employed at the SEC, the "investor welfare approach," and OMB, the "total surplus approach," would come into conflict and that solving this mismatch should be prioritized. Yoon-Ho Alex Lee, The Efficiency Criterion for Securities Regulation: Investor Welfare or Total Surplus?, 57 ARIZ. L. REV. 85, 107-18 (2015). Lee concludes that there is significant dissonance between the approaches and that "any effort to impose a more rigorous cost-benefit analysis requirement for the SEC rules should be preceded by resolving" the question of how to evaluate "efficiency for securities regulation." Id. at 128 . Further, Lee notes that his study is limited to the SEC, but claims it is conceivable that other financial agencies would have similar discrepancies with executive practices that would necessitate action prior to the extension of executive review. Id. In a separate piece, Lee demonstrates the conflict underlying his concern by exploring how cost-benefit analyses might diverge when accounting for solely investor welfare versus including additional stakeholders including "managers, gatekeepers, vendors, employees, consumers and taxpayers." Yoon-Ho Alex Lee, SEC Rules, Stakeholder Interests, and Cost-Benefit Analysis, 10 CAP. MKTS. L.J. 311,314 (2015).

348. While the FSOC plays a coordinating role in member agency policymaking and rulemaking, Dodd-Frank $\S 112(a)(2)(E)$, when the FSOC directly promulgated rules on its own accord, OIRA review is required because the FSOC is an Executive Branch agency and not an "independent regulatory agency." 44 U.S.C. $\$ \S 3502(1), 3502(5)$; Exec. Order No. 12,866, § 3(b), 3 C.F.R. 638 (1994). After the 1994 Executive Order was issued, $\S 3502$ was amended, changing the sub-section listing independent agencies from (10) to (5), a minor change reflected in later Executive Orders, e.g., Exec. Order $13,211, \S 4(\mathrm{c})(2001)$. 
agency, ${ }^{349}$ these regulations are subject to OIRA review. So far, the FSOC has conducted three rulemakings. First, in 2011, the Council promulgated a rule implementing the Freedom of Information Act. ${ }^{350}$ Understandably, that rule was not designated a "significant regulatory action." 351 That same year, the FSOC issued a rule to "set forth the standards and procedures governing the Council's designation of a financial market utility" as "systemically important." 352 The rule, which enables a key function of the Council, was designated as a "significant regulatory action" though it was not deemed "economically significant," meaning the regulation was determined not to have an economic impact of greater than $\$ 100$ million or "adversely affect in a material way the economy, a sector of the economy, productivity, competition, jobs, the environment, public health or safety, or State, local, or tribal governments or communities." 353 For significant regulatory actions that are not economically significant, OIRA does not require a detailed, quantified analysis of an action and potential alternatives. ${ }^{354}$ The rule was reviewed, ${ }^{355}$ but there is no publicly available evidence of correspondence, commentary, or meetings. Finally, in 2012, the FSOC finalized a rule on "standards and procedures governing Council determinations ... whether a nonbank financial company shall be supervised" by the Federal Reserve and "subject to prudential standards." 356 The rule followed a similar path through the bureaucratic structure: it was submitted to OIRA and deemed a "significant regulatory action" but not an "economically significant" one. ${ }^{357}$

Despite the potential importance of the FSOC's two substantive rulemakings, OIRA's engagement was perfunctory as a result of the way in which the FSOC classified the rules. ${ }^{358}$ It seems totally implausible that rules designed to prevent economic crises should be labeled not "economically significant." Presumably, the FSOC follows this strategy as a way to evade meaningful OIRA review. As long as it continues to do so, it will fail to benefit from OIRA's cost-benefit expertise.

\footnotetext{
349. See supra text accompanying note 302.

350. Implementation of the Freedom of Information Act, 76 Fed. Reg. 17,038 (Mar. 28,2011 ) (codified at 12 C.F.R. $\$ 1301$ ).

351. Id. at 17,040 .

352. Authority to Designate Financial Market Utilities as Systemically Important, 76 Fed. Reg. 44,763, 44,773 (July 27, 2011) (codified at 12 C.F.R. $\S 1320$ ).

353. Exec. Order No. 12,866, §3(f)(1), 3 C.F.R. 638 (1994); Authority to Designate Financial Market Utilities, 76 Fed. Reg. at 44,773.

354. Exec. Order No. 12,866, $\$ \S 6$ (b)-(c), 3 C.F.R. 638 (1994);

355. Authority to Designate Financial Market Utilities, 76 Fed. Reg. at 44,773.

356. Authority to Require Supervision and Regulation of Certain Nonbank Financial Companies, 77 Fed. Reg. 21,637 (Apr. 11, 2012) (codified at 12 C.F.R. $\S 1310$ ).

357. Id. at 21,651; see Bartlett supra note 10, at 387.

358. See Hester Peirce, Economic Analysis by Federal Financial Regulators 9-10 (Mercatus Ctr., Working Paper No. 12-31, 2012).
} 


\section{Building Economic Expertise in Individual Agencies}

Financial regulatory agencies could also take unilateral steps to improve their quantification capabilities. Here, the example of Executive Branch agencies can also be instructive. For example, the EPA has longstanding experience and deep expertise on cost-benefit analysis. ${ }^{359}$ As a result, Judge Douglas Ginsburg of the D.C. Circuit has suggested that the SEC should aim to emulate the EPA's cost-benefit practices. ${ }^{360}$

Since 1971, the EPA has undertaken economic research and analysis. ${ }^{361}$ The agency first developed an internal blueprint for quantification in $1983 .{ }^{362}$ In September 2000, the EPA published its Guidelines for Preparing Economic Analysis, "revised to reflect the evolution of environmental policy making and economic analysis that had accrued." 363 The 300-page manual is billed as "part of a continuing effort ... to develop improved guidance on the preparation and use of sound science in support of the decision-making process" and contains, among others, sections on "Statutory and Executive Order Requirements for Conducting Economic Analysis," "Statement of Need for Policy Action," "Baseline," "Discounting Future Benefits and Costs," "Analyzing Benefits," "Analyzing Costs," Economic Impact Analyses," and "Presentation of Analysis and Results." 364 This document has been periodically updated by the National Center for Environmental Economics (NCEE), ${ }^{365}$ a group within the EPA that is responsible for taking the lead on quantified analysis and serves as a "clearinghouse for economics within the agency.", 366 Additionally, the EPA Science Advisory Board has a standing committee, the Environmental Economics Advisory Committee, which scrutinizes the agency's economic analysis as "a peer review system dedicated to economic questions." 367

Today, the EPA's economic analysis capacity is formidable. In fact, "there are probably more economists working on environmental issues employed at the EPA than at any other single institution in the world." EPA has more economists than OIRA's total staff. ${ }^{369}$ Its NCEE, which employs "dozens of economists," sits within the Office of Policy at the EPA, which "has been characterized as a 'mini-OMB' within the agency" for its contributions to

\footnotetext{
359. Livermore, supra note 131 , at 625 .

360. See Bartlett, supra note 10, at S396.

361. Al McGartland, Thirty Years of Economics at the Environmental Protection Agency, 42 AGRIC. \& RESOURCE ECON. REV. 436, 438 - 41 (2013)

362. EPA Guidelines, supra note 76 , at 1-1.

363. Id

364. Id. at i to $\mathrm{v}, 1-1$.

365. Id. at $1-1$

366. Livermore, supra note 131 , at 628.

367. Id. at 629 .

368. Id. at 627 (citing Richard D. Morgenstern, The Legal and Institutional Setting for Economic Analysis at EPA, in ECONOMIC ANALYSES AT EPA: ASSESSING REGULATORY IMPACT 14 (Richard D. Morgenstern ed., 1997)).

369. Id.
} 
the analysis of the impacts of regulations. ${ }^{370}$ The NCEE is responsible for core economic functions such as providing analytical advice to other EPA components, disseminating guidance on cost-benefit analysis across the agency, and funding outside projects. ${ }^{371}$ The NCEE also serves as a "training ground" for economists who ultimately leave for jobs elsewhere in the EPA or other federal regulatory agencies, which is an acknowledgment of its proficiency and competence. ${ }^{372}$ Despite the EPA's robust internal capacities, it often solicits outside expertise, engaging consultants in economic projects, including "the preparation of regulatory-impact analyses," as well as turning to the scholars at Science Advisory Board's Environmental Economics Advisory Committee for input. $^{373}$

Underscoring the EPA's economics capacity is a wealth of research and resources. For example, an EPA inventory of reports the agency completed or funded contains "over 660 reports prepared between 1971 and 2011" alone, roughly one hundred of which the EPA executed itself, with the rest delegated to external actors. ${ }^{374}$ EPA's internal capabilities and external engagement on matters of quantification and economic analysis are a paragon of agency economics capabilities in the modern regulatory state. The extensive support the agency receives demonstrates the advantages Executive Branch agencies enjoy and hints at the potential that "independent" agencies might one day reach given the right resources, synergies, and executive direction.

As indicated above in Part I.B, to its credit the SEC has recently begun to follow Judge Ginsburg's advice and taken significant steps to improve its economic capabilities. But those efforts, which are ones that the EPA took more than two decades ago, are still very recent. Nonetheless, among financial regulatory agencies, the SEC is acknowledged to have become the leader in the economic analysis of regulations. ${ }^{375}$ The other agencies are further behind and would be well advised to begin taking serious steps in this direction.

\section{Role of Judicial Review}

This Part explores the differences between OIRA review and judicial review of agency action. It takes aim at the misconception that agency costbenefit analysis is subject to judicial review only when it is required by statute, showing that any cost-benefit analysis prepared by an agency, to satisfy OIRA review or otherwise, is subject to judicial review under the Administrative Procedure Act. But OIRA review of the cost-benefit analysis of the

370. Livermore, supra note 131, at 627 (citing THOMAS O. MCGARITY, REINVENTING RATIONALITY: THE ROLE OF REGULATORY ANALYSIS IN THE FEDERAL BUREAUCRACY 256 (1991)).

371. Id. at 627-28.

372. Id. at 628 .

373. Id.

374. Id. at 630 .

375. ROSE \& WALKER, supra note 5, at v. 
independent financial regulatory agencies is likely to produce more deferential judicial review. This Part therefore adds further support for the proposition that the financial regulatory agencies would benefit from such review.

\section{A. OIRA Review v. Judicial Review}

The literature on financial services regulation devotes significant attention to the distinction between OIRA review and judicial review. The core idea expounded in this literature is that if the requirement for cost-benefit analysis stems from Executive Order 12,866 rather than from a judicial interpretation of the agency's substantive statute, the quality of the cost-benefit analysis would not be judicially reviewable. In the most significant of these articles, Professor Robert Bartlett asserts that "the fact that agencies are not required to engage in CBA but do so voluntarily generally forecloses the possibility that this CBA would be subject to judicial review." 376

Contrary to this type of claim, any fact on which the agency relied in making its decision is subject to review under the "arbitrary and capricious" standard of the Administrative Procedure Act. So, if an agency prepares a costbenefit analysis, the quality of that analysis is fair game when the rule gets challenged in court, regardless of whether the cost-benefit analysis was undertaken voluntarily. ${ }^{377}$

In fact, there are many examples of cases in which federal administrative agencies had their cost-benefit analyses dissected by the courts even under statutes that do not require the use of cost-benefit analysis. In these cases, the challenges were based on the Regulatory Impact Assessment that the agency prepared to comply with the Executive Order.

For example, in Center for Biological Diversity $v . N H T S A,{ }^{378}$ the Ninth Circuit took issue with the National Highway Traffic Safety Administration's "Average Fuel Economy Standards for Light Trucks" rule, ${ }^{379}$ finding it "arbitrary and capricious," in part due to a "failure to monetize the value of carbon emissions." 380 The Ninth Circuit did not find that cost-benefit analysis was required under the Energy Policy and Conservation Act, the statute under which the rule was promulgated. But it rejected the argument that the Act "prohibits NHTSA's use of marginal cost-benefit analysis" in creating fuel economy standards. ${ }^{381}$ Then, the Ninth Circuit criticized NHTSA for "put[ting] a thumb on the scale" by weighing an analysis of the costs of regulation such as "employment and sales impacts" without similarly counting the benefits of

376. Bartlett, supra note 10 , at S389.

377. See Caroline Cecot \& W. Kip Viscusi, Judicial Review of Agency Benefit-Cost Analysis, 22 GEO. MASON L. REV. 575, 591 (2015).

378. 538 F.3d 1172 (9th Cir. 2008).

379. 71 Fed. Reg. 17,566 (Apr. 6, 2006) (codified at 49 C.F.R. pt. 533).

380. 538 F.3d at 1181 ; see Cecot \& Viscusi, supra note 377 , at $596-97$.

381. 538 F.3d at $1182-83,1197$. 
carbon reduction. ${ }^{382}$ So, even though cost-benefit analysis was not explicitly required of NHTSA, its analysis was scrutinized because the agency employed it in making its rule. And, because the Ninth Circuit found this analysis deficient, it struck down the rule. This case stands for the proposition that, "[g]enerally speaking, if an agency relies on a [cost-benefit analysis], the court will evaluate whether the [analysis] is reasonable." 383 The cases also show that "courts have encouraged comprehensive assessment of benefits and costs in some contexts," even when the governing statute does not speak to the required scope of cost-benefit analysis. ${ }^{384}$

Bartlett's misconception about the nature of judicial review of administrative action probably stems from a provision in Executive Order 12,866 , which states in the second sentence of Section 10: "This Executive order is intended only to improve the internal management of the Federal Government and does not create any right or benefit, substantive or procedural, enforceable at law or equity by a party against the United States, its agencies or instrumentalities, its officers or employees, or any other person." ${ }^{385}$ He believes that the quality of an agency's cost-benefit analysis will not be reviewable by a court if an agency undertakes it merely to comply with the Executive Order and not as a result of a judicial interpretation of the agency's substantive statute.

Instead, what this provision means is that a court cannot review the question of whether an agency complied with the requirements of the Executive Order. Failure to comply with such requirements is not reason for setting aside a rule. For example, a court cannot set aside a regulation on the grounds that the agency did not submit it to OIRA for review in violation of the Executive Order.

Moreover, the first sentence of Section 10 explicitly states: "Nothing in this Executive order shall affect any otherwise available judicial review of agency action." ${ }^{386}$ So, the Executive Order does not purport to affect in any way the rules that govern judicial review of agency action. And even if it attempted to do so, such a provision would be invalid because an Executive Order cannot change the requirements of a statute. ${ }^{387}$

From his misconception about the nature of judicial review of administrative action, Professor Bartlett constructs a substantive argument favoring the use by the financial regulatory agencies of cost-benefit analysis that is reviewable within the Executive Branch but not by the courts. He notes that "there is certainly much to like in a CBA framework that seeks to coordinate interagency CBA through a centralized agency, much like what

\footnotetext{
382. Id. at 1198 .

383. Cecot \& Viscusi, supra note 377 , at 591.

384. Id. at 598 .

385. Exec. Order No. 12,866, § 10, 3 C.F.R. 638 (1994).

386. Id.

387. See Chamber of Commerce v. Reich, 74 F.3d 1322, 1324 (1996) (striking down President Clinton's Executive Order 12,954 for conflicting with the National Labor Relations Act).
} 
OIRA does in the context of [environmental, health, and safety] regulations. Indeed, OIRA itself could serve this function . . ..,388

In contrast, he argues that "empowering judges to review regulators' CBA likely does more harm than good to the extent that the goal is to promote wellinformed economic analysis." 389 He argues that "[t]his system, which eschews judicial review in favor of an effectively unenforceable obligation to comply with an interagency review of CBA mandates, may hold the greatest promise for encouraging a more uniform and transparent application of CBA across financial regulators whole avoiding the critique that CBA leads to regulatory paralysis and delay." 390

But Bartlett faces a formidable hurdle in his effort to explain the mechanism under which the financial regulatory agencies will conduct costbenefit analysis subject to OIRA or other centralized review but will then be able to shield this analysis from judicial review. In this regard, he "suggests the advisability of moving toward a system similar to what applied to the [Office of the Controller of the Currency] prior to the Dodd-Frank Act." example does not support his argument.

Prior to the passage of the Dodd-Frank Act, which designated the OCC as an independent agency, ${ }^{392}$ the OCC had to submit the regulatory analysis for its significant actions to OIRA for review. ${ }^{393}$ However, the OCC's analysis was largely protected from judicial review under the statutes giving the OCC authority to promulgate rules. ${ }^{394}$ For example, the International Lending Supervision Act of 1983, which allowed the OCC to promulgate capital requirements for banks, "generally insulate[d] bank-capital-adequacy requirements from judicial review," a provision spurred by prior "judicial second-guessing of bank regulators' decision to declare struggling banks to be undercapitalized." The Act specifically gives "[e]ach appropriate Federal banking agency ... the authority to establish such minimum level of capital for a banking institution as the appropriate Federal banking agency, in its discretion, deems to be necessary or appropriate." ${ }^{396}$ When such suits challenging the capital requirements arose, courts found that such decisions are "committed to agency discretion by law." 397 This limitation on review applied

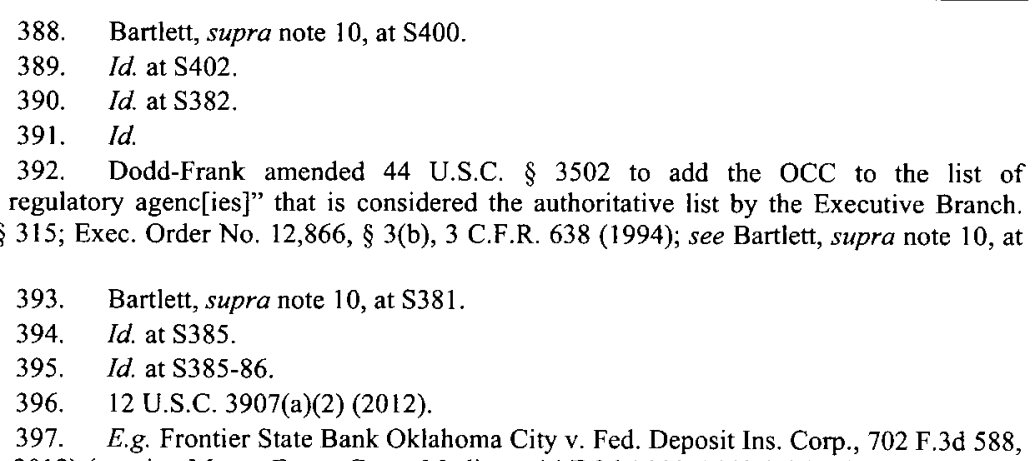
595 (10th Cir. 2012) (quoting Mount Evans Co. v. Madigan, 14 F.3d 1444, 1449 (10th Cir. 1994)). Prior 
to the agency decision as a whole, and not only to a particular analytical component of the decision, such as judicial review.

The "committed to agency discretion by law" exception to judicial review is an extremely narrow one in American administrative law. The carve out was meant to apply only to a few "rare instances where "statutes are drawn in such broad terms that in a given case there is no law to apply.",398 Following DoddFrank's imposition of heightened judicial review on the OCC ${ }^{399}$ only the FDIC and the Federal Reserve are protected from judicial review of cost-benefit analysis among the financial agencies. ${ }^{400}$ And, most importantly, the courts have never said that the cost-benefit analyses performed by agencies should not be reviewable if the agency decisions are otherwise reviewable. Accomplishing Bartlett's objective would require exempting the decisions of the financial regulatory agencies from judicial review altogether. Bartlett does not provide a credible explanation for how this could happen in light of the requirements of the Administrative Procedure Act. In fact, no such mechanism is available.

Despite the misguided nature of this quest, other prominent commentators have followed suit, though in a more aspirational manner, expressing the view that it would be desirable to have Executive Branch review substitute for judicial review. For example, Professor Robert Jackson, Jr. notes that "regardless of the position one takes as to the appropriate role of CBA, all should agree that the judiciary is not the institution that should conduct that analysis." ${ }^{401}$ But unlike Bartlett, Jackson acknowledges, at least implicitly, the challenge of having an agency conduct a cost-benefit analysis that cannot be challenged in the courts. To make this outcome possible, he calls on Congress to "expressly limit judicial review of financial-regulation CBA.," ${ }^{, 402}$ In effect, under Professor Jackson's proposal, the usual Administrative Procedure Act rules on "arbitrary and capricious" review would not apply to the judicial review of the cost-benefit analyses of financial regulatory agencies.

Other scholars expound similar thinking about the undesirability of judicial review of financial cost-benefit analysis. According to Coates "court review of quantified [cost-benefit analysis] is unlikely to improve [it] significantly, at least not without adding costs that are of the same order as the

to the International Lending Supervision Act, the OCC had a capital requirement order rejected as arbitrary and capricious. See First Nat. Bank of Bellaire v. Comptroller of the Currency, 697 F.2d. 674 (5th Cir. 1983); Eric Posner \& E. Glen Weyl, Benefit-Cost Paradigms in Financial Regulation 4-5 (U. Chi. Coase-Sandor Inst. for L. \& Econ. Research Paper No. 660, 2014), http://chicagounbound. uchicago.edu/cgi/viewcontent.cgi?article=1647\&context=law_and_economics.

398. Ronald M. Levin, Understanding Unreviewability in Administrative Law, 74 MinN. L. REV. 689, 704 (1990) (quoting Citizens to Preserve Overton Park, Inc. v. Volpe, 401 U.S. 402, $410(1971))$.

399. See Sharkey, supra note 177, at 1640-42 (citing Dodd Frank $\S 1044$ ).

400. See Bartlett, supra note 10, at S382 fig.1.

401. Robert J. Jackson, Jr., Comment: Cost-Benefit Analysis and the Courts, 78 L. \& CONTEMP. ProBs. 55, 59 (2015).

402. Id. at 63 . 
benefits of such review." 403 Similarly, Kraus writes that many feel "that courts should get out of the business of second-guessing [cost-benefit analysis in financial regulation], and that current statutory attempts to amplify judicial review would do more harm than good.",404 Ryan Bubb argues that "there are options for institutionalizing CBA in financial regulation other than legal mandates subject to judicial review ... or complete agency autonomy. In particular, a CBA and regulatory-review regime for the independent financial regulatory agencies could be fashioned along the lines of OIRA review." And prominent non-governmental organizations want to "insulate new rulemakings from judicial challenge."

Even if it were desirable for Executive Branch review to displace judicial review, there is no way to get there absent congressional action. If a financial regulatory agency prepares a cost-benefit analysis for the purpose of an OIRAlike regulatory review, even if such analysis is not required by statute, the adequacy of this analysis can be challenged at the judicial review stage. Of course, an agency might refrain from performing cost-benefit analysis if not mandated by statute and nevertheless survive judicial review. However, should an agency perform a cost-benefit analysis, whether it is required by an OIRAlike body, statute, both, or even not required at all, there is no reason that a court would examine the regulatory impact analysis under a standard other than "arbitrary and capricious" in considering the quality of an agency's cost-benefit analysis.

\section{B. Deference}

Even though OIRA review cannot be a substitute for judicial review, there is an important relationship between the two. If the courts perceive that the Executive Branch has a robust mechanism for reviewing the quality of the costbenefit analyses performed by administrative agencies, they are more likely to be deferential in reviewing these analyses. As Professor Catherine Sharkey notes, when there exists "rigorous executive oversight," courts may employ a more deferential standard "centered on the reasonableness of the agency's actions." ${ }^{407}$ Conversely, she argues that heightened judicial review, what she terms "State Farm with teeth," 408 should be applied to independent agency

403. John C. Coates IV, Cost-Benefit Analysis of Financial Regulation: A Reply, 124 YALE L.J.F. 305, 307 (2015), http://www.yalelawjournal.org/forum/cost-benefit-analysis-of-financialregulation-a-reply.

404. Kraus, supra note 4 , at 282.

405. Bubb, supra note 9, at 52.

406. COMM. ON CAPITAL MKTS. REgUlation, supra note 190 , at 3 ; contra MCClOSKEY \& PEIRCE, supra note 6, at 1 (advocating for judicial review of cost-benefit analysis of financial regulation).

407. Sharkey, supra note 177 , at 1592.

408. State Farm set out the "hard look" framework for judicial review of agency decisions under the "arbitrary and capricious" standard. Motor Vehicle Mfrs. Ass'n, Inc. v. State Farm Mut. Auto. Ins. Co., 463 U.S. 29, 30 (1983); Kagan, supra note 320, at 2372, 2380. 
rulemakings because they do not undergo OIRA review. ${ }^{409}$ So, while there is no mechanism in the administrative state to accomplish Bartlett's objective of Executive Branch review but no judicial review, the former can make the latter more deferential because it is likely to make the courts more confident of the rigor in the agency's regulatory analysis.

In the absence of rigorous executive review of agency regulatory analysis, "judicial review . . . can be information forcing," creating better agency records and decisions. ${ }^{410}$ After all, despite the shortcomings in expertise exhibited by generalist courts, stringent judicial review forces agencies to provide "reasoned explanations backed by sufficient scientific references." 411 This burden forces agencies to seek the most efficient and least burdensome ways to meet what is statutorily required of them. ${ }^{412}$ To create this incentive, Sharkey proposes a more stringent State Farm standard for agencies whose analyses do not undergo Executive Branch vetting, to "incentivize data-driven (and hence, better) agency decision-making." 413

Of course, if more stringent review is appropriate for agencies that do not undergo Executive Branch review, it reasonably follows that those that are subject to such vetting deserve more deferential review. Sharkey embraces this view and advocates "that a court should take into account whether OIRA has given its imprimatur to the agency's cost-benefit analysis when calibrating the level of scrutiny it directs to the task at hand." ${ }^{214}$ This perspective is based on the nature and extent of Executive Branch review, which is "information forcing" in that it has led agencies to grow their ranks of economists and pay more attention to "creating a robust regulatory record of the net benefits of proposed rules."

Sharkey imagines that, under the framework she proposes, an "agency might trade a dimension of its independence for a degree of insulation from otherwise-heightened judicial review." with less stringent judicial review may incentivize independent agencies to submit their cost-benefit analyses to OIRA for review. ${ }^{417}$ This deference

409. Sharkey, supra note 177 , at 1604 . Sharkey believes such a heightened standard is on display in Business Roundtable. Id. at 1593, 1630-31.

410. Id. at 1604 .

411. Id. at 1605 .

412. See id.

413. Id. at 1604. Others find Sharkey's proposal unwise, arguing that her "proposal ignores the fundamental feature of agency decisionmaking under conditions of severe uncertainty." Jacob Gersen \& Adrian Vermeule, Thin Rationality Review 114 MICH. L. REV. 1355, 1384 (2016).

414. Sharkey, supra note 177 , at 1619.

415. Id. at $1620-22$.

416. Id. at 1634. Under this scheme, OIRA's "regleprudential norms," meaning how OIRA has treated "the systematic analysis of regulation refracted through accounts of the role and nature of the law," may "help reinforce the institution's significance during judicial review." Nestor M. Davidson \& Ethan J. Leib, Regleprudence-at OIRA and Beyond, 103 GEO. L.J. 259, 261, 294 n.175 (2015)

417. See Sharkey, supra note 177 , at 1634 
paradigm adds another strong argument for subjecting the decisions of the independent financial regulatory agencies to Executive Branch review.

\section{Conclusion}

If the discussion concerning the use of cost-benefit analysis in the environmental and financial areas had taken place fifty years ago, the competing positions would likely have been very different. Unlike now, at that time cost-benefit analysis was not a core part of the analytical apparatus of the administrative state and the techniques for valuing benefits were not developed in either area. Imagine a situation in which a group of experts was asked then to predict which area would be more amenable to cost-benefit methodologies in the future: the area in which regulations deal with financial markets or the one in which they deal with the protection of human lives and the environment. It is almost certain that the group would have said that financial regulation was more amenable to cost-benefit analysis. Changes in market performance are associated with quantitative metrics, whereas changes in health, life expectancy, or visibility are not.

In retrospect, these experts would have been wrong. The valuation techniques in the environmental arena have become well developed, commonplace, and relatively well accepted across a range of the political spectrum, including among the prominent commentators who disagree about the feasibility of cost-benefit analysis for financial regulation. These advances were fueled in large part by the Executive Orders in effect since the Reagan Administration, which created strong incentives for the development of appropriate techniques, and by federal funding that promoted such research.

In contrast, the valuation techniques for ascertaining the benefits of financial regulation are very much in their infancy. Why might that change? This Article has shown the deep shortcomings of independent agencies in general, and of the financial regulatory agencies in particular, with respect to the preparation of cost-benefit analyses in rulemaking. As a result of these shortcomings, many significant rules have fared poorly in the courts, giving rise to a defeatist debate about whether such cost-benefit analysis is even possible.

This debate detracts attention from the important institutional issue at stake: given that the requirement that the financial regulatory agencies justify some of their rules in cost-benefit terms is here to stay, and is likely to become even more prevalent, what institutional structures are best able to perform this task? And, fortunately, there are good models within the Executive Branch to guide this inquiry, particularly with respect to environmental regulation. The path will undoubtedly be a difficult one, but the direction is clear. The institutions and practices that have served us well in one area are available to the other. We just need to embrace the lessons that we have learned over the past several decades. 